\title{
A SOCIOECONOMIA DA COMUNIDADE RURAL FAZENDA DO POVO DE IPIAÚ, BAHIA, BRASIL
}

\author{
SOCIOECONOMIC ANALYSIS OF RURAL \\ COMMUNITY FAZENDA DO POVO, IPIAÚ \\ MUNICIPALITY, BAHIA, BRAZIL
}

\author{
Bruno, Nelma Lima ${ }^{1}$ \\ Aguiar, Paulo César Bahia de ${ }^{2}$ \\ Profice, Christiana Cabicieri ${ }^{3}$ \\ Ferraz, Marcelo Inácio Ferreira ${ }^{4}$ \\ Universidade Estadual de Santa Cruz, Ilhéus, Bahia
}

1 Geografa pela Universidade do Estado da Bahia - UNEB Campus VI de Caetité. Mestra em Desenvolvimento Regional e Meio Ambiente pela Universidade Estadual de Santa Cruz - UESC, em Ilhéus, Bahia, Brasil. E-mail: nelmalima06@hotmail.com

2 Geógrafo e Mestre em Desenvolvimento Regional e Meio Ambiente pela Universidade Estadual de Santa Cruz - UESC, em Ilhéus, Bahia, Brasil. E-mail: prof.pauloaguiar@bol.com.br

3 Doutora em Psicologia Social pela Universidade Federal do Rio Grande do Norte, Brasil. Professora Adjunta do Departamento de Filosofia e Ciências Humanas da UESC. E-mail: ccprofice@uesc.br

4 Doutor em Estatística e Experimentação Agropecuária pela Universidade Federal de Lavras - UFLA. Professor Titular do Departamento de Ciências Econômicas e Tecnológicas da Universidade Estadual de Santa Cruz. E-mail: mfferraz@uesc.br

Fecha de recepción: 12 de febrero de 2016

Fecha de aceptación: 3 de junio de 2016 
Bruno, Nelma Lima; Aguiar, Paulo César Bahia de; Profice, Christiana Cabicieril; Ferraz, Marcelo Inácio Ferreira. Socioeconomic analysis of rural community fazenda do Povo, Ipiaú Municipality, Bahia, Brazil

\title{
RESUMO
}

O principal objetivo dessa pesquisa foi analisar a realidade socioeconômica da Comunidade Rural Fazenda do Povo de Ipiaú, Bahia, no contexto da sua sustentabilidade ambiental em relação à socioeconomia municipal e regional. Analisaram-se, para isso, indicadores socioeconômicos da região, do município de Ipiaú, e da comunidade. Os resultados apontaram situação positiva da comunidade no que se refere ao nível de escolaridade, comparando-se à realidade de outros assentamentos de reforma agrária; à questão da renda e da renda per capta; à baixa dependência de benefícios sociais do Governo; e à ocupação do trabalho. E apontaram como negativo a grande frequência de agroquímicos utilizados no manejo da produção.

Palavras-chave: Comunidade rural, assentamento de reforma agrária, desenvolvimento, sustentabilidade.

\begin{abstract}
The main objective of this research was to analyze the socioeconomic reality of the Rural Community Fazenda do Povo of Ipiaú, Bahia, in regards to municipal and regional socio-economy. Therefore, socioeconomic indicators in the region, the city of Ipiaú, and the community were analyzed. The results showed a positive situation of the community regarding schooling, compared to the reality of other settlements of agrarian reform; the issue of income and per capita income; the low dependence on government social benefits; and job covering. Besides, they showed how negative the high frequency of agrochemicals used in the management of production is.
\end{abstract}

Keywords: Rural community, agrarian reform settlement, development, sustainability.

\section{Introdução}

O conceito de desenvolvimento de um país, cidade ou comunidade, foi por muito tempo utilizado para indicar seu patamar de crescimento socioeconômico. Mais recentemente, com a incorporação da ideia de sustentabilidade, o desenvolvimento não é visto como um processo sem limites, ele encontra constrangimentos à sua evolução determinados pelos aspectos naturais e sociais do contexto real. Desse modo, a avaliação da sustentabilidade ambiental de uma comunidade é efetuada pelo levantamento de indicadores das dimensões naturais (biofísicas), sociais e econômicas. Contudo, apesar da sustentabilidade tridimensional ser um consenso, o equilíbrio e hierarquia entre as dimensões está longe de ter sua discussão esgotada (Mauerhofer, 2008). Se considerarmos o natural, o social e o econômico sem uma hierarquia entre eles, a sustentabilidade será alcançada com a união simples dos três, cada dimensão correspondendo a um terço do resultado final. Consequentemente, se ao menos duas das dimensões estiverem satisfatórias, já garantimos dois terços da sustentabilidade. Nesta perspectiva, se uma comunidade promove o bem estar social e bom desempenho econômico, mesmo que seus aspectos naturais 
sejam completamente degradados e ignorados ela está próxima de um desenvolvimento considerado sustentável. Temos também correntes que consideram a dimensão econômica como a determinante das demais e assim o pleno desenvolvimento da economia, sobretudo pelo mercado, vai garantir a qualidade das dimensões sociais e naturais. Como apontamos acima, o famoso tripé da sustentabilidade encontra diferentes equilíbrios em virtude da dimensão enfatizada. Neste trabalho adotamos a ideia da sustentabilidade tridimensional proposta por Mauerhofer (2008), conforme a qual as três dimensões, naturais, sociais e econômicas são determinadas por suas respectivas capacidades, por sua vez limitadas por seus respectivos capitais. Nosso trabalho trata da sustentabilidade ambiental em uma comunidade rural do sul do Estado da Bahia, com enfoque na sua socioeconomia. Nesse sentido, o principal objetivo desse estudo foi avaliar a sustentabilidade ambiental da Comunidade Rural Fazenda do Povo de Ipiaú, Bahia, relacionando-a a socioeconomia municipal de Ipiaú, e a socioeconomia regional.

Iniciamos com uma breve discussão teórica dos conceitos adotados, sustentabilidade ambiental e desenvolvimento de comunidades rurais. Em seguida apresentamos os métodos, procedimentos e instrumentos utilizados em nossa pesquisa. Ainda apresentamos e discutimos os dados acerca dos aspectos sociohistóricos e da paisagem atual da CRFP, do contexto socioeconômico recente da microrregião Ilhéus-Itabuna (microrregião de inserção da CRFP) e do município de Ipiaú. Analisamos a socioeconomia da comunidade em seus aspectos sociais econômicos e produtivos para finalmente apontar os desafios ao desenvolvimento socioeconômico da CRFP e tecer nossas considerações finais.

\section{Referencial Teórico}

\section{Sustentabilidade Ambiental}

Como assinalamos na introdução a sustentabilidade ambiental é tridimensional, ainda que não haja consenso acerca da articulação e hierarquia entre as dimensões naturais, sociais e econômicas. Mauerhofer (2008) propõe seu modelo 3-D no qual o capital natural constitui o limite da sustentabilidade já que nosso planeta, como unidade biofísica, tem limites reais quanto à utilização de seus recursos e degradação dos 
seus ecossistemas. Apenas a energia solar é um recurso infinito e de fato sem custos. Ainda assim, nos processos industriais devolvemos calor à atmosfera, bem como resíduos poluentes que podem interferir no seu equilíbrio, no que hoje denominamos mudanças climáticas. Hoje temos clareza, ao menos na comunidade científica, de que não apenas exploramos os recursos biofísicos com uma intensidade insustentável como também criamos problemas ambientais de longo prazo a partir de nosso padrão de produção e consumo. Assim, a dimensão ambiental engloba as demais e define seus limites.

A partir do reconhecimento desta hierarquia, a dimensão social se coloca como a seguinte, determinando como será o uso e a distribuição dos recursos naturais e de seus serviços. O capital social alimenta a capacidade social e sua promoção deve ser orientada pelo princípio da equidade na direção da sustentabilidade. Se houver uma distribuição equitativa dos recursos, mas também dos problemas ambientais, a capacidade social será aumentada por meio da plena realização do capital social. Por fim, a dimensão econômica é interna às demais, não é ela quem dita as regras, ela é a própria regra determinada pela dimensão social e vai ser consequente ao padrão de produção e consumo por ela promovido. Como salienta Mauehofer (2008), é possível um mundo natural sem um mundo social, mas o contrário não. Também já presenciamos na história humana sociedades sem economia, mas não economias sem sociedade.

Nossa investigação traz o entendimento do desenvolvimento não apenas como crescimento econômico, mas principalmente vinculado à sustentabilidade ambiental, reconhecendo os limites do mundo natural e levando em consideração aspectos culturais e aqueles relacionados ao bem-estar e qualidade de vida das comunidades e sociedades humanas, em que a equidade social, a satisfação das necessidades básicas de saúde, educação, trabalho, lazer, e a democracia participativa são elementos primordiais para sua realização. Neste sentido, os aspectos locais ganham relevância e, associados a demais indicadores socioeconômicos, envolvem a realização de potencialidades socioculturais e econômicas das comunidades em equilíbrio com os aspectos naturais do ambiente. Em se tratando de comunidades rurais, a sustentabilidade local é desafiada também pela conjuntura regional, nacional e global. Ficam cada vez mais resumidas as diferenças tradicionais entre o rural e o urbano,

ISSN 1011-484X, julio-diciembre 2016, pp. 289-331 
levando a que possam ser identificadas tanto comunidades rurais em estágio pleno de desintegração ou decomposição, até comunidades mais ou menos organizadas (Toledo, 1996).

\section{Sustentabilidade e Desenvolvimento de Comunidades Rurais}

Para a palavra "comunidade" foram formulados diferentes conceitos no transcorrer do tempo a partir de realidades concretas, os quais possibilitaram o avanço no estudo e compreensão de distintos agrupamentos humanos, levando-se em consideração diferentes dimensões. Esses estudos, dentro de uma visão holística, comumente tomam como ponto de partida os grupos humanos na ligação entre seus membros e destes com o ambiente.

Considerando-se as diferentes concepções existentes na literatura, neste estudo adotou-se como conceito privilegiado de comunidade a de um lugar de moradia e convivência entre os moradores, os quais estabelecem laços de afetividade e o sentimento de pertencimento, e no qual vivenciam as mesmas dificuldades, necessidades, problemas e representações sociais em um território compartilhado geograficamente ocorrendo a identificação com o lugar e com as pessoas (Góis, 2005). A comunidade se trata de um lugar heterogêneo, por conseguinte, nela também emergem conflitos em razão das contradições que ocorrem; no entanto, por meio do diálogo promove-se a transformação dos moradores e da própria comunidade, sem que com isso ocorra a perda do sentimento em relação ao local (Góis, Ibidem).

A definição precisa do que vem a ser comunidade rural ainda é um desafio. No entanto, algumas características são apontadas pela literatura para identificar comunidades rurais. Segundo Youmans (1982), o rural descreve uma área que é dependente socialmente, culturalmente e economicamente de recursos naturais - terra, água, madeira, minerais, montanhas.

Por sua vez, Kageyama (2004) pontua que as discussões sobre a definição de rural são praticamente inesgotáveis, mas parece haver certo consenso sobre os seguintes pontos: o rural não é sinônimo de agrícola e nem tem exclusividade sobre este; o rural é multissetorial (pluriatividade) e multifuncional (funções produtivas, ecológicas, sociais); as áreas rurais tem densidade populacional relativamente baixa; não há um isolamento absoluto entre os espaços rurais e as áreas urbanas. Redes mercantis, sociais e institucionais se estabelecem entre o rural e as cidades e vilas adjacentes. 
Bruno, Nelma Lima; Aguiar, Paulo César Bahia de; Profice, Christiana Cabicieril; Ferraz, Marcelo Inácio Ferreira. Socioeconomic analysis of rural community fazenda do Povo, Ipiaú Municipality, Bahia, Brazil

A vida em comunidade rural concebida a partir de uma visão tradicional, segundo Brandemburg (2010), assume um caráter de relativa autonomia, uma especificidade tipicamente rural. Essa autonomia é tão maior à medida que o distanciamento dos centros mais urbanizados ou cidades dificulta o contato dos seus moradores, que raramente se deslocam para a cidade com o intuito de adquirir objetos complementares à sua sobrevivência ou mesmo para comercializar produtos. A troca de produtos ou a comercialização é assim o primeiro passo para abertura da comunidade rural para o mundo exterior.

No entanto, ao analisar o ambiente rural na modernidade, Brandemburg (Ibidem) aponta que este tem sido tratado de forma distinta pelos estudiosos. Alguns estudiosos sinalizam que o rural está em processo de desaparecimento, sobretudo nos países modernizados, à medida que a modernização e a industrialização dos espaços produtivos destroem as formas de organização social que tem na agricultura camponesa ou familiar suas bases fundamentais. Nessa perspectiva, o rural emerge como um espaço de atividades e profissões diversas, submetido à racionalidade do capital. Outros estudiosos apontam que o rural é reconstruído por atores diversos, dentre os quais o agricultor familiar, principal personagem de um rural ancorado na tradição da vida social camponesa.

Segundo Carneiro (2013), no Brasil pesquisas recentes têm apontado para a ocorrência de dois conjuntos de fenômenos no meio rural que tem ajudado a pensar a questão da ruralidade:

Em primeiro lugar, o espaço rural não se define mais exclusivamente pela atividade agrícola. [...] é significativa a redução de pessoas ocupadas na agricultura, dado que se associa ao aumento do número de pessoas residentes no campo exercendo atividades não-agrícolas e ao aparecimento de uma camada relevante de pequenos agricultores que combinam a agricultura com outras fontes de rendimento. $\mathrm{O}$ segundo conjunto de fenômenos refere-se à procura crescente de formas de lazer e até mesmo de meios alternativos de vida no campo, por pessoas vindas da cidade (Ibidem, p. 56-57).

Outra tendência indicada por pesquisadores brasileiros dos ambientes rurais é o simultâneo envelhecimento e masculinização da população rural (Camarano e Abramovay, 1998). Os jovens de um modo geral deixam o campo em busca de melhores oportunidades de estudo e

Revista Geográfica de América Central No 57 ISSN 1011-484X, julio-diciembre 2016, pp. 289-331 
profissionalização, as moças em especial buscam um novo lugar familiar e social menos rígido e hierarquizado próprio das cidades (Ibidem).

Amartya Sen (2010), de forma holística, conceitua o desenvolvimento como "expansão das liberdades", ou seja, a produção de mais democracia, em que "o desenvolvimento pode ser encarado como um processo de alargamento das liberdades reais de que uma pessoa goza". Nessa perspectiva, "a liberdade é nuclear ao processo de desenvolvimento por duas ordens de razões: 1. Avaliação: apreciação do progresso tem de ser feita em termos do alargamento das liberdades das pessoas; 2. Eficácia: a eficácia do desenvolvimento depende da ação livre das pessoas". De forma instrumental, sob essa ótica, cinco são as espécies de liberdade: a) liberdades políticas; b) disponibilidades econômicas; c) oportunidades sociais; d) garantias de transparência; e) proteção da segurança.

Como discutimos, a sustentabilidade nas comunidades rurais se revela como a busca contínua do equilíbrio entra as dimensões naturais, sociais e econômicas, no qual se combinem práticas, agrícolas ou não, que protejam os recursos naturais e proporcionem maior equidade social, e de forma a garantir maior independência em relação a insumos externos (Caporal e Costabeber, 2002). Portanto, analisar a realidade socioeconômica desses espaços é primordial para a compreensão do estágio em que se encontram, possibilitando a adoção de políticas públicas e a autonomia para alcançarem a autogestão, relacionando a economia, o ambiente e a sociedade. Desenvolver estudos com essa finalidade, tendo como base as especificidades locais e regionais de cada contexto, é primordial para o entendimento desses ambientes e para a busca da construção de comunidades sustentáveis.

\section{Método, Procedimentos e Ferramentas}

A pesquisa foi realizada nos anos de 2014 e 2015, a partir de aprovação do Comitê de Ética em Pesquisa com Seres Humanos da Universidade Estadual de Santa Cruz, Ilhéus, Bahia, sob protocolo $n^{\circ}$ 832.751. Antes da pesquisa propriamente dita foram realizadas visitas preliminares para apresentação da proposta de investigação e obtenção do aval da comunidade. A pesquisa envolveu etapas de campo e laboratório, as quais são especificadas a seguir. 
Bruno, Nelma Lima; Aguiar, Paulo César Bahia de; Profice, Christiana Cabicieril; Ferraz, Marcelo Inácio Ferreira. Socioeconomic analysis of rural community fazenda do Povo, Ipiaú Municipality, Bahia, Brazil

\section{Etapa De Laboratório}

A etapa de laboratório consistiu no levantamento de material bibliográfico e documental; e dados secundários junto ao Instituto Brasileiro de Geografia e Estatística - IBGE, ao Departamento de Informática do Sistema Único de Saúde do Brasil - DATASUS e ao Programa das Nações Unidas para o Desenvolvimento - PNUD; tabulação desses dados e também dos dados e informações obtidos em campo (construção de gráficos e tabelas no Excel, e processamento e análise de dados pelo Statistical Package for the Social Science - SPSS versão 20 - e posterior análise e interpretação); envolveu ainda a elaboração de documento cartográfico (mapa de uso e ocupação da terra da CRFP). Os dados primários com as informações obtidas por meio das observações in loco permitiram a análise de indicadores socioeconômicos da comunidade; e os diversos pontos obtidos em GPS possibilitaram, em Imagem de Satélite Google Earth/GMS 2015, a delimitação da área de abrangência da comunidade, a identificação da localização das unidades produtivas na imagem, a classificação dos diferentes usos e ocupações da terra, e a elaboração de documento cartográfico síntese (mapa de uso e ocupação da terra), por meio do Programa ArcGis 10.2.2.

\section{Etapa de Campo}

A etapa de campo consistiu em levantamento de dados primários, observações em diferentes áreas da comunidade e nas Unidades Produtivas, e registro em Sistema de Posicionamento Global - GPS de diferentes pontos de localização. Para a efetivação da pesquisa utilizou-se de técnicas de documentação direta, por meio da aplicação de formulário semiestruturado a 111 representantes de famílias. Apenas duas famílias não aceitaram participar da pesquisa, quatro famílias indicadas não foram encontradas, uma família se mudou na ocasião antes de ser entrevistada, e doze casas se encontravam fechadas. Na ocasião forma coletados pontos de GPS, tanto de delimitação da área de abrangência da comunidade, quando de localização das unidades produtivas.

\section{Instrumento}

O Instrumento utilizado para coleta de dados primários foi um formulário semiestruturado, construído de forma definitiva após um pré-teste e uma reunião participante na comunidade, contendo dados sociais,

Revista Geográfica de América Central No 57 ISSN 1011-484X, julio-diciembre 2016, pp. 289-331 
econômicos, produtivos e indicadores prioritários - e aplicado a 111 representantes de famílias. Foi aplicado ainda um segundo formulário semiestruturado apenas àquelas famílias que possuíam unidades produtivas familiares, com questões voltadas, sobretudo, aos aspectos de produção. Os indicadores prioritários contidos no primeiro formulário semiestruturado receberam tratamento e analise especial, e não são apresentados aqui, pois compõem outro artigo.

\section{Área de Estudo}

O município de Ipiaú encontra-se localizado na Mesorregião Sul Baiano, Microrregião Ilhéus-Itabuna (Figura 1), conforme regionalização para o Estado da Bahia proposta pelo Instituto Brasileiro de Geografia e Estatística - IBGE (divisão regional com base no predomínio de uma cidade - aglomeração urbana - sobre o espaço regional), nas coordenadas geográficas de latitude de $14^{\circ} 08^{\prime} 13^{\prime}$ 'S e de longitude de 39\%44'02"O. Este município dista em torno de $185 \mathrm{~km}$ da capital do estado (PNUD, 2000), possui uma área da unidade territorial de $267,33 \mathrm{~km}^{2}$ (IBGE, 2010), com população de 44.390 habitantes e densidade demográfica de 166 hab. $/ \mathrm{km}^{2}$ (IBGE. CENSO DE 2010). No que se refere às suas fronteiras territoriais, limita-se com os seguintes municípios: ao Norte, com o município de Jequié; ao Nordeste e ao Leste, com o município de Ibirataia; ao Sudeste, com o município de Barra do Rocha; ao Sul, com o município de Itagibá; ao Sudoeste, com o município de Aiquara; e, ao Oeste, com o município de Jitaúna.

O Índice de Desenvolvimento Humano Municipal de Ipiaú (IDH-M) no ano de 2010 foi de 0,670 , colocando-o na condição de médio desenvolvimento humano. O PIB do ano de 2012 foi de $\mathrm{R} \$ 308.537 .000,00$, o que representava $0,18 \%$ do PIB do Estado da Bahia. Já o PIB per capita no ano de 2012 foi de $R \$ 6.927,50$, o qual o colocava na $104^{a}$ posição entre os 417 municípios baianos. 
Bruno, Nelma Lima; Aguiar, Paulo César Bahia de; Profice, Christiana Cabicieril; Ferraz,

Marcelo Inácio Ferreira. Socioeconomic analysis of rural community fazenda do Povo, Ipiaú

Municipality, Bahia, Brazil

Figura 1. Localização do município de Ipiaú na

Microrregião Ilhéus-Itabuna, Bahia

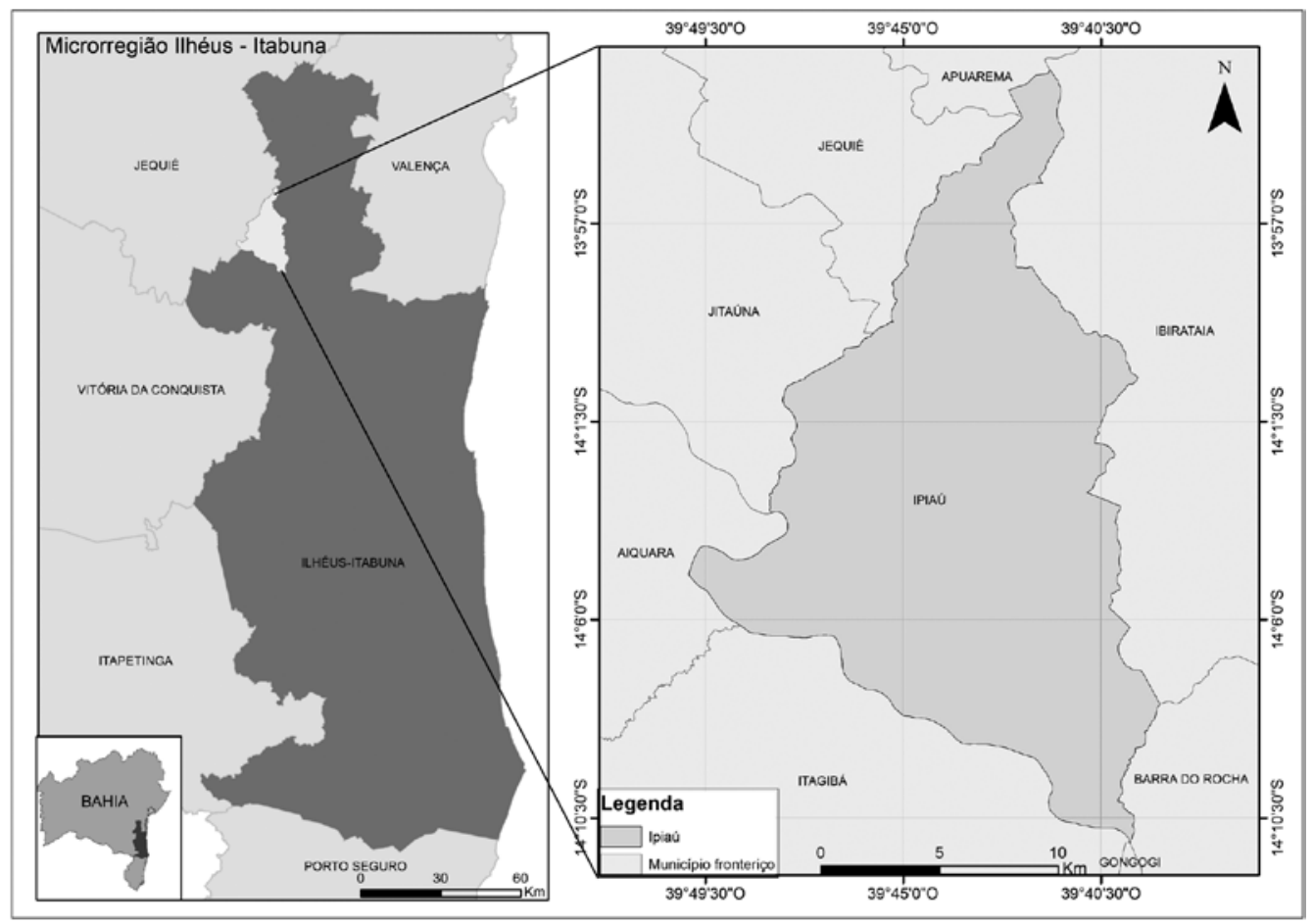

Elaboração: Moreira, Tássio (2016), por meio do programa ArcGis 10.2.2.

Duas bacias hidrográficas têm seus principais rios passando pelo município: o rio de Contas e o rio Água Branca. A sua geologia predominante se caracteriza por gnaisses e metatexitos (Superintendência de Geologia e Recursos Minerais - SGM, 1994); a vegetação característica é a de Floresta Ombrófila Densa (RADAMBRASIL, 1981-1983); o Bioma onde está inserido é o da Mata Atlântica; e o clima predominante da região onde se encontra é Úmido e Subúmido a Seco (Superintendência de Estudos Econômicos e Sociais da Bahia. Atributos Climáticos do Estado da Bahia, 1998) - e, conforme classificação de Köppen, define-se como clima do tipo tropical úmido “Am”. A Comunidade Rural Fazenda do Povo (CRFP) está localizada no município de Ipiaú, na Mesorregião Sul Baiano, Microrregião Ilhéus-Itabuna, Estado da Bahia, Nordeste do Brasil, nas coordenadas 
geográficas de latitude $14^{\circ} 3^{\prime} 21.19^{\prime}$ 'S e longitude $39^{\circ} 42^{\prime} 39.15^{\prime \prime} \mathrm{W}$, possui uma área da unidade territorial de 157 hectares e 25 ares com cerca de 140 famílias residentes, e dista $11 \mathrm{~km}$ da sede municipal (Figura 2).

\section{A Comunidade Rural Fazenda do Povo (CRFP)}

\section{Aspectos Sociohistóricos}

Criada pelo Poder Público Municipal de Ipiaú no ano de 1963, por meio do Decreto-Lei 965 que desapropriou para fins de reforma Agrária a Fazenda Santo Antônio, na região do Bom Sem Farinha, nos meses iniciais da administração do prefeito Euclides Neto, a CRFP foi a primeira experiência oficial de reforma agrária no Estado da Bahia.

Figura 2. Localização da Comunidade Rural Fazenda do Povo no município de Ipiaú, Bahia

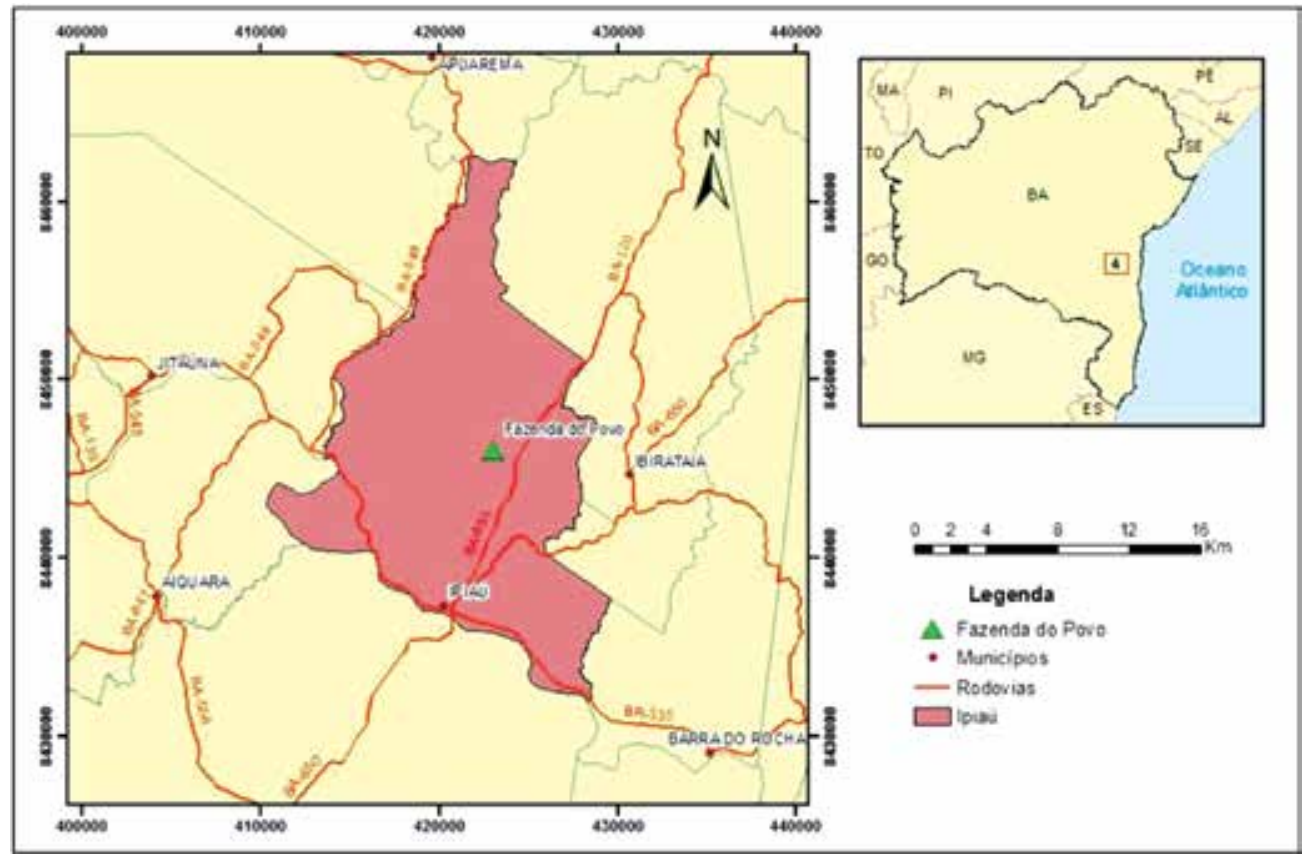

Elaboração: Shigueaki, M., 2014.

O objetivo principal da criação dessa comunidade foi amparar as famílias de trabalhadores rurais demitidos das fazendas locais (e outras 
Bruno, Nelma Lima; Aguiar, Paulo César Bahia de; Profice, Christiana Cabicieril; Ferraz, Marcelo Inácio Ferreira. Socioeconomic analysis of rural community fazenda do Povo, Ipiaú Municipality, Bahia, Brazil

famílias que posteriormente vieram de diferentes municípios por distintas razões), e em virtude da grande seca ocorrida na região entre 1962 e 1963, a qual trouxe como consequência a diminuição na produção de cacau (monocultura predominante na região à época), e, por conseguinte, a demissão de grande número de trabalhadores, bem como pelas condições precárias de trabalho (submissão e escravização da mão-de-obra familiar) a que eram submetidos no período. A conjuntura nacional à época de sua criação, no que se refere às questões rurais, se caracterizou pela acentuação das contradições entre trabalhadores rurais sem terra e os proprietários da terra. Conquanto o governo nacional do período fosse considerado um governo populista, no entanto, acentuava-se um processo de valorização e exploração direta da terra por parte dos proprietários, os quais passaram a negar aos trabalhadores sem terra o direito de utilizá-las (Andrade, 1994). Isso passou a ocorrer, sobretudo, em razão da expansão capitalista no campo, o que propiciou a valorização da terra e aumento na utilização de insumo de capital. Por sua vez, os trabalhadores rurais sem terra passaram a se organizar em associações e a reivindicarem a extensão de certos direitos trabalhistas ao campo (Andrade, Ibid.).

No ano de 1963, a burguesia nacional influenciou diretamente o Parlamento, e este aprovou o Estatuto do Trabalhador Rural, com a finalidade de expandir na agricultura as relações capitalistas de produção [tendo como modelo a "Revolução Verde"]. Além disso, no ano de 1964, com receio da possibilidade da realização de mudanças por parte do governo populista na estrutura da sociedade, a ala conservadora juntamente com os militares depôs o governo populista e instalaram o sistema de governo de regime militar (Andrade, Ib.). Nesse mesmo ano de 1964, o governo militar aprova o Estatuto da Terra (Lei No 4.504) - "primeiro documento que tratou da reforma agrária na história do Brasil", embora "o objetivo do governo não era aplicar a Lei, mas sim controlar os conflitos por terra" (Fernandes, 2008, p. 29).

Com a implantação do regime militar, vários governantes municipais (gestores públicos) de tendências socialistas foram investigados, perseguidos, ou mesmo depostos. Esse foi o caso de Euclídes Neto que, em razão da criação da Comunidade Rural Fazenda do Povo, foi investigado e teve um processo contra si instaurado, no entanto, não chegou a ter seu mandato de prefeito cassado. Conquanto a criação da CRFP seja um marco

Revista Geográfica de América Central No 57 ISSN 1011-484X, julio-diciembre 2016, pp. 289-331 
no processo de assentamento de trabalhadores rurais sem terra à terra, ela difere, em sua origem, da maioria dos outros tipos de assentamentos de reforma agrária presentes atualmente na Microrregião Ilhéus-Itabuna, e a nível de regiões do país, sobretudo por ter sido criada por iniciativa do Poder Público Municipal, e ainda ser administrada por este (ou seja, não envolveu a ocupação, o acampamento e o conflito pela terra), enquanto os outros assentamentos (Projetos de Assentamento Rural - PAs), sob a égide do Incra, normalmente tiveram sua origem por meio da ocupação, do acampamento e do conflito pela terra. No Brasil, além dos PAs federais sob a égide do Incra, existem os assentamentos implementados por políticas estaduais e por políticas municipais (Bergamasco, 1997).

Durante o período de vigência do sistema de governo do regime militar que comandou o país (1964 a 1985), os trabalhadores rurais, em suas lutas por acesso a terra e uma reforma agrária justa, sofreram várias repressões, em diferentes pontos do território nacional. Organizaram-se de diferentes formas, ocuparam terras (entre os anos de 1979 e 1985), obtiveram apoio, por exemplo, da Pastoral da Terral, e formaram o MST (Movimento dos Trabalhadores Rurais Sem Terra), tendo como referências outros movimentos camponeses, a exemplo das Ligas Camponesas. O Estado Brasileiro, por sua vez, como forma de corresponder a algumas reinvindicações dos trabalhadores rurais mobilizados, fez algumas intervenções pontuais, por meio de regras contidas no Plano Nacional de Reforma Agrária, de 1985.

No sul da Bahia, as primeiras ocupações de terra se deram a partir de 1984, por meio da "'luta dos posseiros", quando da ocupação da fazenda Puxim (município de Canavieiras) e das fazendas Sarampo, Francônia e Serra da Onça (no atual município de Santa Luzia). Destas, as fazendas Puxim e Sarampo foram as primeiras desapropriadas pelo INCRA com a finalidade de reforma agrária, em 1985, após ocorreram vários conflitos e mortes; embora o Projeto de Assentamento Rural Puxim/Sarampo tenha sido oficialmente criado somente no ano de 2001 (Freitas, 2009 apud Meliani, 2014). Esse movimento de ocupação não teve o envolvimento do MST. Segundo dados do INCRA (2015), atualmente o Estado da Bahia possui um total de 674 Projetos de Assentamentos Rurais (os quais se encontram em diferentes fases de implementação), em área total de 2.009.945,12 hectares, e um total de 46.915 famílias assentadas. Desse total de PAs, 395 possuem mais de dez anos de criados, e contém 31.349 
famílias assentadas; e 279 PAs possuem menos de dez anos de criados, e contém 15.566 famílias assentadas. Para a Microrregião Ilhéus-Itabuna, conforme dados do INCRA (2011), havia registro de 85 Projetos de Assentamentos Rurais. Não havia registro de nenhum PA para o município de Ipiaú nos dados do INCRA, pois a CRFP oficialmente não está enquadrada nessa categoria.

\section{Paisagem Atual da CRFP}

Um exame atual da paisagem da CRFP revela um mosaico nas características de usos e ocupações da terra, os quais deixam evidente se tratar de uma comunidade eminentemente rural na qual a base de sustentação está ligada ao setor primário da economia municipal. Esse mosaico é reflexo dos diferentes tipos de apropriações e usos do território feitos ao longo de sua existência. Tais usos e ocupações são frutos das ações dos próprios moradores sobre o território conforme suas necessidades, ou mesmo ações de agentes externos ao local sobre o lugar, que culminam na feição atual da sua paisagem. Nesse mosaico percebem-se as atividades econômicas desenvolvidas e outras deixadas de lado, substituições ou mesmo supressões de vegetação, ocupações do território com infraestruturas sociais e produtivas, dentre outros diferentes aspectos.

No mosaico da paisagem atual da comunidade identificam-se os seguintes tipos de uso e ocupação da terra: represa, brejo, áreas de cacau desenvolvidas sob o sistema cabruca, plantios de cana, áreas de capoeira, cascalheira, plantios de mandioca, plantios de olericultura, áreas de pastagem, áreas de pomar, piscicultura desativada e área residencial (Figura 3). Há um maior predomínio de áreas de pastagens, seguido de áreas utilizadas com o plantio de cacau sob o sistema cabruca. Percebe-se pela grande presença de áreas de pastagens e de capoeira que a vegetação nativa foi largamente retirada ao longo da existência da comunidade.

A infraestrutura social e produtiva da comunidade se caracteriza por apresentar nove estradas de chão que permitem a circulação dentro da comunidade; 117 residências habitadas; 15 residências em construção; 12 casas desocupadas; três mercearias; cinco bares; uma Igreja Católica em funcionamento; uma Igreja Evangélica em funcionamento; duas Igrejas Evangélicas em construção; um campo de futebol; uma área demarcada para construção de quadra poliesportiva; um salão de reuniões 
da associação comunitária; uma casa de farinha comunitária em funcionamento; uma escola municipal com duas salas de aula multisseriadas até a quarta série primária ( $5^{\circ}$ ano); uma casa de farinha particular; dois alambiques particulares; energia elétrica em todas as residências com pagamento de conta pelos próprios moradores à Coelba - Companhia Elétrica do Estado da Bahia; um cemitério; um poço artesiano que enche duas caixas d'águas de 20.000 litros as quais abastecem as residências para uso doméstico - sistema totalmente mantido pelo Poder Público $\mathrm{Mu}$ nicipal; um espaço de informática particular (centro de inclusão digital); duas represas comunitárias; uma cascalheira; transporte escolar público do município para a cidade nos três turnos, com saída da comunidade nos horários das 7:00hs, 12:00hs e 18:00hs; transporte coletivo particular com destino a cidade, com saída da comunidade às 6:30hs, 6:40hs e 7:00 hs, e retorno da cidade para a comunidade às 11:30hs e 12:00hs (disponibilidade apenas pela manhã); e coleta de resíduo sólido por parte do poder público municipal, por meio de caçamba, uma vez por semana - normalmente quarta ou quinta-feira. 
Bruno, Nelma Lima; Aguiar, Paulo César Bahia de; Profice, Christiana Cabicieril; Ferraz,

Marcelo Inácio Ferreira. Socioeconomic analysis of rural community fazenda do Povo, Ipiaú

Municipality, Bahia, Brazil

Figura 3. Uso e ocupação da terra na área de abrangência da CRFP de Ipiaú (Bahia), 2015

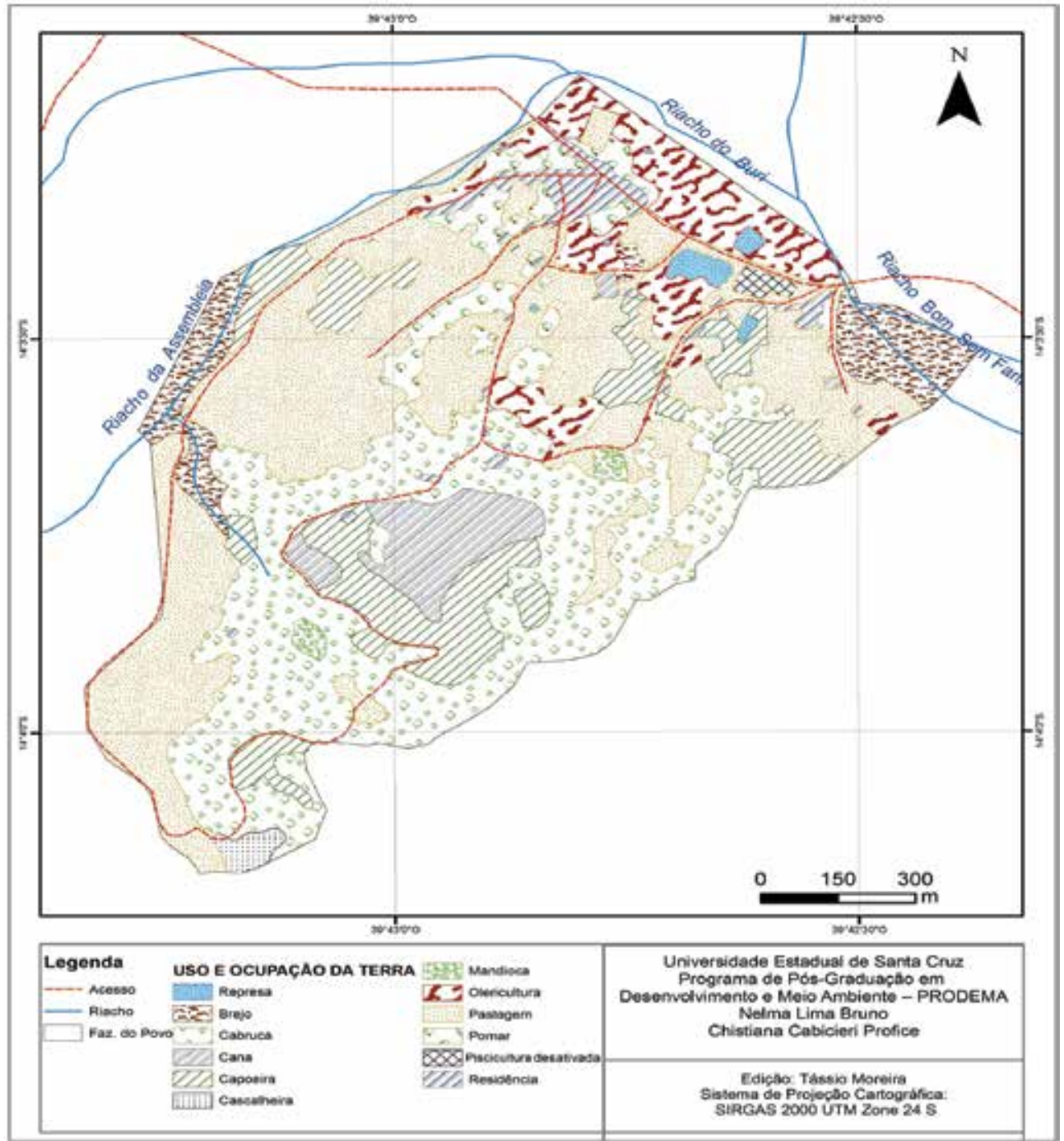

Fonte: Google Earth/GMS (2015), Elaborado por Tássio Moreira.

\section{Contexto Socioeconômico Recente Da Microrregião Ilhéus- Itabuna (Microrregião de Inserção da CRFP)}

Entender a realidade socioeconômica atual do município de Ipiaú e da CRFP passa pela compreensão, a partir de uma visão panorâmica, da 
realidade socioeconômica da Microrregião Ilhéus-Itabuna em suas transformações por causa de fatores internos à própria microrregião, ou mesmo externos a ela (contexto nacional e internacional), os quais a impactaram diretamente. Essas transformações foram sentidas nos diferentes municípios da microrregião de forma diferenciada, reorganizando-os hierarquicamente conforme as funções desenvolvidas e serviços ofertados por seus centros urbanos, o nível de desenvolvimento alcançado, o número da população municipal, a velocidade e capacidade de responder às influências externas, dentre outros fatores.

No transcurso do século XX o sul da Bahia se caracterizou por ter na monocultura do cacau a sua principal atividade econômica, concentradora da mão-de-obra regional, dinamizadora da realidade socioeconômica dos municípios, responsável, juntamente com outros fatores conjugados, pelo surgimento e/ou desenvolvimento de povoados e municípios, ascensão ou mesmo declínio de políticos ao poder, pela formação de uma microrregião denominada cacaueira, por possibilitar o sustento de famílias e o enriquecimento de fazendeiros, e se constituir em um signo do desenvolvimento regional (Rocha, 2008). Atividade econômica essa que passou por diversas crises, sendo que a mais grave teve início em 1987, com fatores internos e externos à região, agravada pela inserção, em 1989, da praga "vassoura-de-bruxa".

Entre os anos de 1990 a 1998 houve oscilação na tendência da utilização dos hectares de terras plantados com cacau na microrregião, ora com aumento nas áreas plantadas, ora com redução. Já de 1998 a 2004, houve uma tendência contínua de redução nas áreas plantadas com cacau, sendo que, em alguns municípios, muitas áreas plantadas com cacau foram substituídas por áreas de pastagem, ou destinadas a outras atividades. Tendência parecida ocorreu na evolução da produção de cacau em toneladas, embora com variações mais frequentes. Nos primeiros anos da década de 2000 a produção de cacau na microrregião foi menor do que a da década de 1990. Essa tendência de oscilações na produção de cacau na microrregião foi seguida pela Bahia e pelo Brasil (Tabela 1), o que causou déficit do produto, levando o país a ter que importa-lo para abastecer as indústrias, as quais, devido a forte demanda do produto, passaram a pagar um ágio (prêmio) em US\$/t no mercado nacional em cima do preço cotado na bolsa de Nova York (Zugaib; Andrade, 2015). 
Bruno, Nelma Lima; Aguiar, Paulo César Bahia de; Profice, Christiana Cabicieril; Ferraz, Marcelo Inácio Ferreira. Socioeconomic analysis of rural community fazenda do Povo, Ipiaú Municipality, Bahia, Brazil

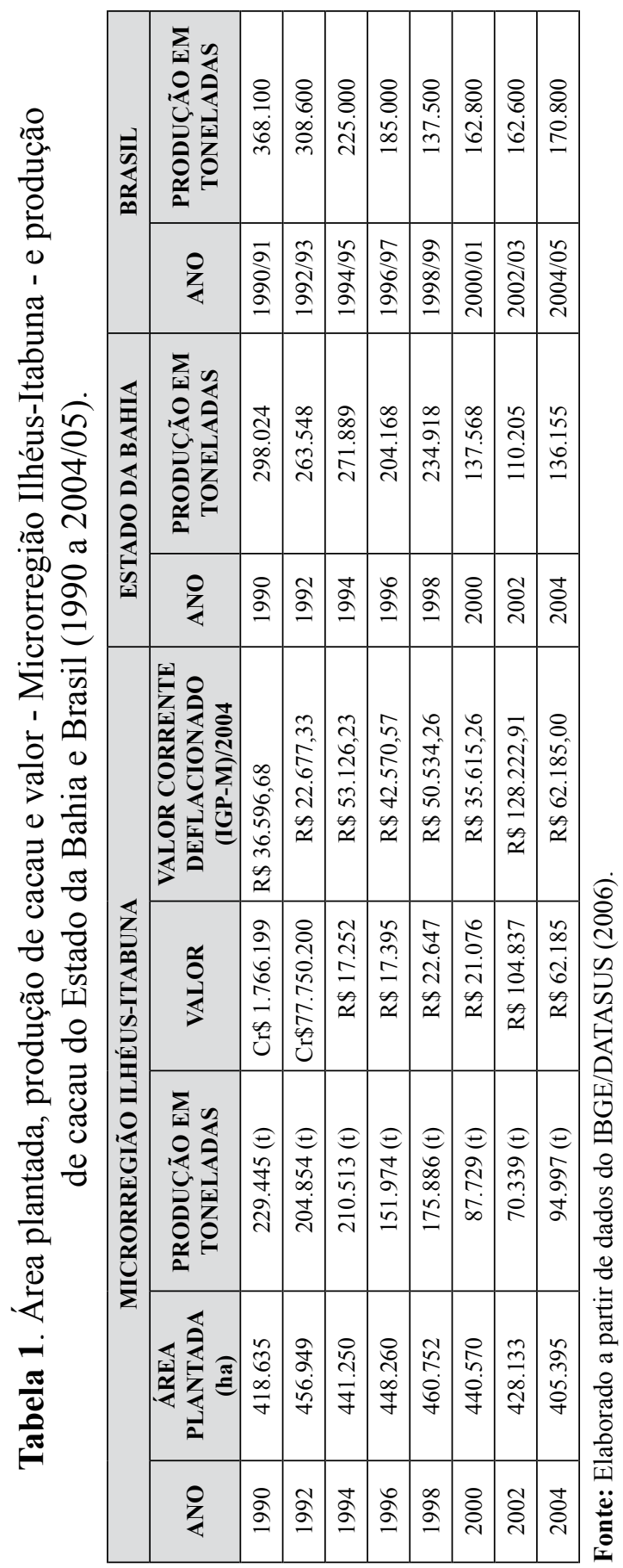


A produção de cacau da Microrregião Ilhéus-Itabuna, conforme pode ser observado pela tabela 1 , representou a maior parcela da produção de cacau do Estado da Bahia e do Brasil. Portanto, o peso maior nas oscilações da produção baiana e nacional era o dessa microrregião, e tiveram como principais causas problemas climáticos locais, a inflação nacional, a falta de visão empreendedora por parte de muitos produtores, o alastramento da praga "vassoura-de-bruxa", e o aumento da produção desse produto em países como Costa do Marfim, Gana e Indonésia - fatores que derrubaram a posição do Brasil para o sexto lugar entre os maiores produtores mundial de cacau em amêndoas, passando a apresentar saldos negativos da balança comercial de cacau e seus derivados (Zugaib; Andrade, Ibidem).

Com essa última crise na cacauicultura alguns municípios da microrregião lentamente passaram por um processo de reorganização socioeconômica, sobretudo entre fins da década de 1990 e primeira década de 2000, e a ter a maior parcela de suas populações concentradas nos espaços urbanos. Embora outros municípios de maior expressão já se encontrassem em processo de reorganização socioeconômica antes dessa crise, a exemplo dos municípios de Itabuna e Ilhéus (Polo Regional), e já tinham passado bem antes pelo processo de inversão da concentração da maior parcela da população do espaço rural para o espaço urbano (seguindo uma tendência nacional), - a exemplo de Ilhéus, Itabuna, Ipiaú, etc. Na tabela 2 , tem-se apresentada a população de 15 dos 41 municípios da atual Microrregião Ilhéus-Itabuna, nos anos de 1980 e 2000. Segundo Rocha (2008), esses quinze municípios foram os mais atingidos na microrregião pelos efeitos da vassoura-de-bruxa. 
Bruno, Nelma Lima; Aguiar, Paulo César Bahia de; Profice, Christiana Cabicieril; Ferraz, Marcelo Inácio Ferreira. Socioeconomic analysis of rural community fazenda do Povo, Ipiaú Municipality, Bahia, Brazil

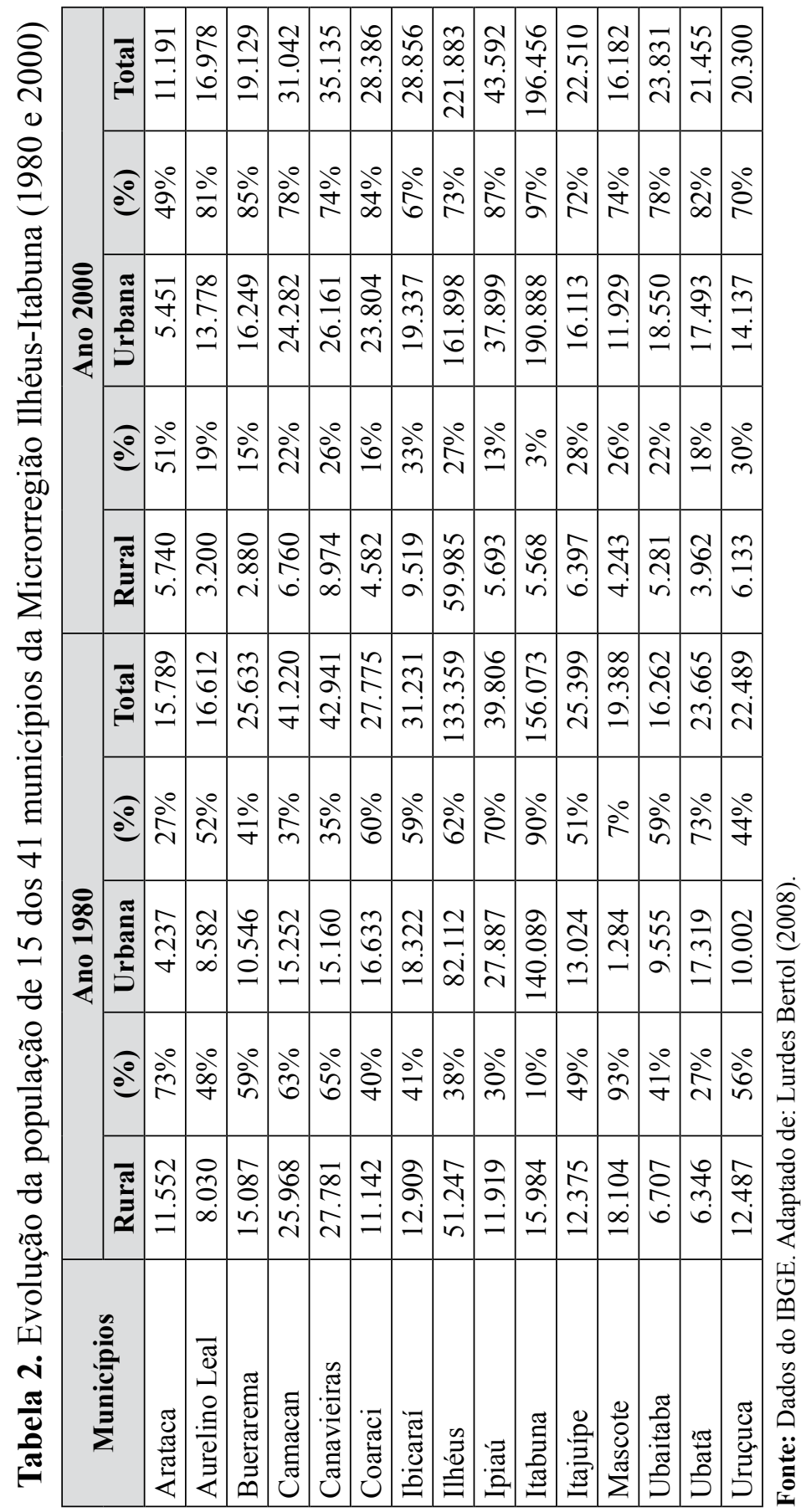




\section{Contexto Socioeconômico Recente do Município de Ipiaú}

Conquanto a praga "vassoura-de-bruxa" tenha se instalado na microrregião em 1989, no entanto, esta não atingiu simultaneamente todos os municípios. Segundo estudo desenvolvido por Rocha (2008), a praga só teria atingido municípios, como, por exemplo, Ipiaú, no ano de 1992, por este município se encontrar a certa distância em relação aos municípios de Uruçuca e Camacan (focos simultâneos iniciais da doença na microrregião).

Entre o ano de 1992 (ano de inserção da vassoura de bruxa no município) e o ano de 1996, a tendência da população total, da produção de cacau e da pecuária bovina no município de Ipiaú foi de declínio - possivelmente essa redução na população total possa estar diretamente associada aos impactos iniciais da vassoura-de-bruxa. A partir de 1996, a tendência da população total do município foi de crescimento entre os anos de 1996 e 2000 (a 2,8\%), ligeira queda entre 2000 e 2004 (a -1,5\%), e tendência de contínuo crescimento entre 2004 e 2010 (a 3,2\%) e entre 2010 e 2013 (a 6,0\%) - conforme especificado na tabela 3.

Por sua vez, a produção de cacau no município, entre os anos de 1996 a 2013, apresentou uma tendência de oscilação: declínio, crescimento e novamente declínio. Já a pecuária bovina, a partir do ano de 1996, apresentou a tendência de crescimento - embora a pecuária bovina do município de Ipiaú, no período compreendido entre os anos de 1990 a 2005, não tenha representado percentual significativo em relação ao da microrregião em nenhum desses anos. A maior representação percentual foi de 1,5\% ocorrida nos anos de 1990, e 2001 a 2005; e a menor representação foi de 1,0\% ocorrida nos anos de 1994, 1995 e 1996. 
Tabela 3. Evolução da população total do município de Ipiaú de 1980 a 2015

\begin{tabular}{|c|c|c|c|c|}
\hline \multirow{2}{*}{ ANO } & \multirow{2}{*}{$\begin{array}{c}\text { POPULAÇÃO } \\
\text { TOTAL }\end{array}$} & \multicolumn{2}{|c|}{ VARIAÇÃO ABSOLUTA } & \multirow{2}{*}{$\begin{array}{c}\text { VARIAÇÃO } \\
\text { RELATIVA } \\
(\%) \\
\end{array}$} \\
\hline & & PERÍODO & VARIAÇÃO & \\
\hline 1980 & 39.806 & - & - & - \\
\hline 1984 & 41.300 & $1980 / 1984$ & 1.494 & $3,6 \%$ \\
\hline 1988 & 43.573 & $1984 / 1988$ & 2.273 & $5,2 \%$ \\
\hline 1991 & 45.245 & $1988 / 1991$ & 1.672 & $3,7 \%$ \\
\hline 1992 & 44.731 & $1991 / 1992$ & -514 & $-1,1 \%$ \\
\hline 1996 & 42.407 & $1992 / 1996$ & -2.324 & $-5,2 \%$ \\
\hline 2000 & 43.621 & $1996 / 2000$ & 1.214 & $2,8 \%$ \\
\hline 2004 & 42.968 & $2000 / 2004$ & -653 & $-1,5 \%$ \\
\hline 2010 & 44.390 & $2004 / 2010$ & 1.422 & $3,2 \%$ \\
\hline 2013 & 47.178 & $2010 / 2013$ & 2.788 & $6,0 \%$ \\
\hline 2015 & $47.501 *$ & $2013 / 2015$ & 323 & $0,7 \%$ \\
\hline
\end{tabular}

Fonte: Elaborado a partir de dados do IBGE - Censos demográficos e contagens populacionais. Disponível em: <http://www.tabnet.datasus.gov.br>

*População estimada para o ano de 2015.

Embora o cacau seja até o presente momento o principal produto agrícola do município de Ipiaú, no entanto, os dados relativos à evolução da população urbana e rural do município permitem inferir que já durante a década de 1990 a agropecuária não era o principal setor produtor de capital no município e agregador da maior parcela da mão-de-obra trabalhadora, pois em 1991 a população urbana do município era de $80 \%$, tendência que só fez aumentar no transcorrer dos anos seguintes - esses dados permitem inferir que o principal setor produtor de capital já na década de 1990 era o setor terciário (setor de serviços), e que esse setor concentrava a maior parcela da mão-de-obra municipal trabalhadora (serviços formais e informais). 
Tabela 4. Distribuição da população do município de Ipiaú nos anos 1980, 1991, 2000 e 2010

\begin{tabular}{|c|c|c|c|c|c|c|c|c|}
\hline \multirow{3}{*}{ ANO } & \multicolumn{8}{|c|}{ DISTRIBUIÇÃO DA POPULAÇÃO MUNICIPAL } \\
\hline & \multirow{2}{*}{ RURAL } & \multirow{2}{*}{$(\%)$} & \multirow{2}{*}{ URBANA } & \multirow{2}{*}{$(\%)$} & \multirow{2}{*}{ TOTAL } & \multicolumn{3}{|c|}{ VARIAÇÃO ABSOLUTA } \\
\hline & & & & & & $1980 / 1991$ & $1991 / 2000$ & $2000 / 2010$ \\
\hline 1980 & 11.919 & $30 \%$ & 27.887 & $70 \%$ & 39.806 & & & \\
\hline 1991 & 8.837 & $20 \%$ & 36.408 & $80 \%$ & 45.245 & & & \\
\hline 2000 & 5.697 & $13 \%$ & 37.924 & $87 \%$ & 43.621 & 5.439 & -1.624 & 769 \\
\hline 2010 & 3.995 & $9 \%$ & 40.395 & $91 \%$ & 44.390 & & & \\
\hline
\end{tabular}

Fonte: Elaborado a partir de dados do PNUD. Atlas de Desenvolvimento Humano no Brasil (1991; 2000). IBGE Censo de 2010.

Ao se analisar o indicador Índice de Desenvolvimento Humano $\mathrm{Mu}-$ nicipal (educação, longevidade e renda) de Ipiaú, observa-se, por meio da tabela 5, que no ano de 1991, seguindo tendência do Estado da Bahia e do Brasil, o município apresentava um IDH-M muito baixo, sendo que a variável que mais contribuiu para isso foi a educação. No ano 2000, o IDH-M do município ainda era baixo, enquanto a Bahia e o Brasil já haviam evoluído para Médio Desenvolvimento Humano. Somente no ano de 2010 é que o município passou a apresentar uma evolução para o IDH-M, igualando-se à Bahia e ao Brasil, com Médio Desenvolvimento Humano - com um índice superior ao do Estado da Bahia, e ocupando a $2663^{\mathrm{a}}$ posição no ranking nacional. A educação continuou sendo a variável mais fraca para Ipiaú.

Tabela 5. IDH-M de Ipiaú, da Bahia e do Brasil (em 1991, 2000 e 2010)

\begin{tabular}{|l|c|c|c|c|c|c|c|c|c|}
\hline \multirow{3}{*}{ INDICADOR } & \multicolumn{3}{|c|}{ IPIAÚ } & \multicolumn{3}{c|}{ BAHIA } & \multicolumn{3}{c|}{ BRASIL } \\
\cline { 2 - 11 } & \multicolumn{3}{|c|}{ ANO } & \multicolumn{3}{c|}{ ANO } & \multicolumn{3}{c|}{ ANO } \\
\cline { 2 - 10 } & $\mathbf{1 9 9 1}$ & $\mathbf{2 0 0 0}$ & $\mathbf{2 0 1 0}$ & $\mathbf{1 9 9 1}$ & $\mathbf{2 0 0 0}$ & $\mathbf{2 0 1 0}$ & $\mathbf{1 9 9 1}$ & $\mathbf{2 0 0 0}$ & $\mathbf{2 0 1 0}$ \\
\hline IDH-M & $\mathbf{0 , 3 6 2}$ & $\mathbf{0 , 4 9 8}$ & $\mathbf{0 , 6 7 0}$ & $\mathbf{0 , 3 8 6}$ & $\mathbf{0 , 5 1 2}$ & $\mathbf{0 , 6 6 0}$ & $\mathbf{0 , 4 9 3}$ & $\mathbf{0 , 6 1 2}$ & $\mathbf{0 , 7 2 7}$ \\
\hline Educação & 0,159 & 0,315 & 0,551 & 0,182 & 0,332 & 0,555 & 0,279 & 0,456 & 0,637 \\
\hline Longevidade & 0,556 & 0,679 & 0,796 & 0,582 & 0,680 & 0,783 & 0,662 & 0,727 & 0,816 \\
\hline Renda & 0,537 & 0,578 & 0,687 & 0,543 & 0,594 & 0,663 & 0,647 & 0,692 & 0,739 \\
\hline
\end{tabular}

Fonte: Elaborado a partir de dados do PNUD. Atlas do Desenvolvimento Humano no Brasil (2013). 
Por sua vez, a renda per capita média de Ipiaú no ano de 1991 foi de $\mathrm{R} \$ 226,77$, no ano 2000 foi de R\$291,77, e em 2010 foi de R\$573,36. Observa-se um crescimento de $152,84 \%$ nas últimas duas décadas na renda per capita média desse município. Houve uma redução no percentual de pobres entre 1991 e 2000 , passando de $68,81 \%$ para $51,39 \%$ (entende-se por pobres aqueles com renda domiciliar per capita menor que $\mathrm{R} \$ 141,00$ - preço corrente em agosto de 2010), e entre 2000 e 2010, passando de $51,39 \%$ para $29,68 \%$.

O indicador Produto Interno Bruto Municipal (PIB-M) além de ser responsável por apontar a distribuição da produção de receitas (capital) em um município, também deixa evidente a distribuição da população economicamente ativa que está trabalhando (formal ou informalmente), por setores de atividade (primário, secundário, terciário). Esse indicador passou a ser oficialmente utilizado no ano de 1999. No período compreendido entre os anos de 1999 a 2012, o principal setor produtor de capital no município de Ipiaú foi o setor terciário, que de forma disparada apresentou o maior percentual na produção de receita no município. Levando-se em consideração o valor adicionado bruto por atividade econômica no PIB-M a preços correntes em $\mathrm{R}$ (Tabela 6), a administração pública se colocava na segunda posição, atrás do setor de serviços. Os dados apontam uma realidade econômica dinâmica do município. 


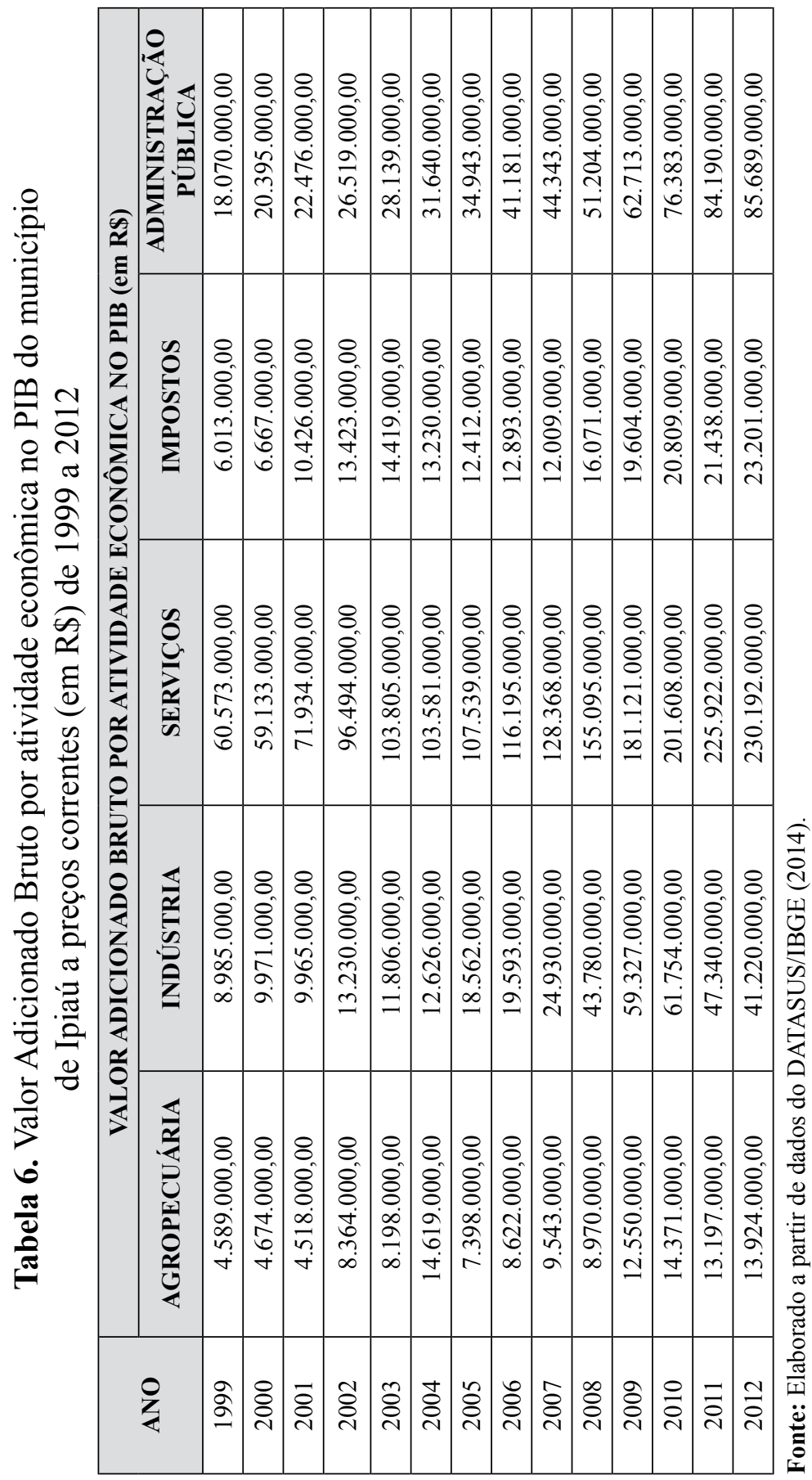


Bruno, Nelma Lima; Aguiar, Paulo César Bahia de; Profice, Christiana Cabicieril; Ferraz, Marcelo Inácio Ferreira. Socioeconomic analysis of rural community fazenda do Povo, Ipiaú Municipality, Bahia, Brazil

Analisando-se os setores de atividades do município no mesmo período, sem a participação da administração pública, o setor da indústria ocupou em todo o período (a exceção de 2004) o segundo lugar na produção de capital, atrás do setor de serviços. A agropecuária de Ipiaú, embora importante para o município, representou em todo o período considerado (a exceção de 2004) o menor percentual dentre os setores de atividade (Tabela 7).

Tabela 7. Participação (\%) das atividades econômicas no PIB do município de Ipiaú, (1999 a 2012)

\begin{tabular}{|c|c|c|c|c|}
\hline ANO & AGROPECUÁRIA & INDÚSTRIA & SERVIÇOS & IMPOSTOS \\
\hline 1999 & $5,70 \%$ & $11,2 \%$ & $75,6 \%$ & $7,50 \%$ \\
\hline 2000 & $5,80 \%$ & $12,4 \%$ & $73,5 \%$ & $8,30 \%$ \\
\hline 2001 & $4,70 \%$ & $10,3 \%$ & $74,3 \%$ & $10,80 \%$ \\
\hline 2002 & $6,40 \%$ & $10,1 \%$ & $73,4 \%$ & $10,20 \%$ \\
\hline 2003 & $5,90 \%$ & $8,5 \%$ & $75,1 \%$ & $10,40 \%$ \\
\hline 2004 & $10,10 \%$ & $8,8 \%$ & $71,9 \%$ & $9,20 \%$ \\
\hline 2005 & $5,10 \%$ & $12,7 \%$ & $73,7 \%$ & $8,50 \%$ \\
\hline 2006 & $5,50 \%$ & $12,5 \%$ & $73,9 \%$ & $8,20 \%$ \\
\hline 2007 & $5,50 \%$ & $14,3 \%$ & $73,4 \%$ & $6,90 \%$ \\
\hline 2008 & $4,00 \%$ & $19,6 \%$ & $69,3 \%$ & $7,20 \%$ \\
\hline 2009 & $4,60 \%$ & $21,8 \%$ & $66,4 \%$ & $7,20 \%$ \\
\hline 2010 & $4,80 \%$ & $20,7 \%$ & $67,5 \%$ & $7,00 \%$ \\
\hline 2011 & $4,30 \%$ & $15,4 \%$ & $73,4 \%$ & $7,00 \%$ \\
\hline 2012 & $4,50 \%$ & $13,4 \%$ & $74,6 \%$ & $7,50 \%$ \\
\hline
\end{tabular}

Fonte: Elaborado a partir de dados do DATASUS/IBGE (2014).

$\mathrm{Na}$ agropecuária municipal os produtos agrícolas que se destacam em produção e valores da produção são: abacaxi, amendoim em casca, banana, cacau (em amêndoa), cana-de-açúcar, coco-da-baía, goiaba, mandioca e maracujá. O coco-da-baía representou em 2013 a maior produção em quantidade em fruto; e a banana, em toneladas; e em valor, o cacau (Tabela 8). 
Tabela 8. Produção Agrícola do município de Ipiaú no ano de 2013

\begin{tabular}{|l|c|c|c|c|c|}
\hline \multirow{2}{*}{ Cultura } & \multicolumn{5}{|c|}{ PRODUÇÃO AGRÍCOLA MUNICIPAL } \\
\cline { 2 - 6 } & $\begin{array}{c}\text { Área } \\
\text { Plantada (ha) }\end{array}$ & $\begin{array}{c}\text { Área } \\
\text { Colhida (ha) }\end{array}$ & $\begin{array}{c}\text { Quantidade } \\
\text { Produzida }\end{array}$ & Unidade & $\begin{array}{c}\text { Valor } \\
\text { (R\$ 1.000) }\end{array}$ \\
\hline Abacaxi & 3 & 3 & 66 & 1000 Frutos & 92 \\
\hline Amendoim (em casca) & 12 & 12 & 11 & $\mathrm{~T}$ & 10 \\
\hline Banana & 750 & 750 & 9000 & $\mathrm{~T}$ & 7.308 \\
\hline Cacau (em amêndoa) & 8145 & 8145 & 2215 & $\mathrm{~T}$ & 11.341 \\
\hline Cana-de-açúcar & 153 & 153 & 7497 & $\mathrm{~T}$ & 975 \\
\hline Coco-da-baía & 17 & 17 & 85 & 1000 Frutos & 43 \\
\hline Goiaba & 3 & 3 & 18 & $\mathrm{~T}$ & 15 \\
\hline Mandioca & 170 & 170 & 1700 & $\mathrm{~T}$ & 432 \\
\hline Maracujá & 18 & 18 & 180 & $\mathrm{~T}$ & 183 \\
\hline
\end{tabular}

Fonte: Elaborado a partir de dados do IBGE - Pesquisa Agrícola Municipal (2013).

Percentualmente, no período de 1999 a 2012, o PIB de Ipiaú (sem os valores correspondentes a participação da administração pública) teve pouca representação no PIB do Estado da Bahia, variando entre a representação mínima de 0,16\% (anos de 2005 a 2007) e a representação máxima de $0,22 \%$ (ano de 2002). Em nível de Brasil, a representação percentual do PIB deste município correspondeu, a cada ano (sem os valores correspondentes a participação da administração pública), de 1999 a 2012, à ínfima participação de $0,01 \%$ do PIB nacional. Por sua vez, o PIB per capita de Ipiaú (sem a participação dos valores da administração pública) ocupou, no mesmo período, a melhor posição no ranking estadual no ano de 1999, quando ocupou a $65^{\mathrm{a}}$ posição. A pior posição foi ocupada no ano de 2007, a $134^{a}$ posição entre os 417 municípios do Estado da Bahia.

\section{A Socioeconomia da Comunidade Rural Fazenda do Povo}

\section{Aspectos Sociais}

A CRFP, segundo dados oficiais do Poder Público Municipal, é composta por 140 famílias. A pesquisa, no entanto, identificou 111 famílias, somando um total de 416 pessoas (correspondendo a $0,9 \%$ da população total do município de Ipiaú estimada para o ano de 2015), dando uma média de 3,7 moradores por residência - as famílias foram computadas pelo 
número de residências pesquisadas e não de famílias contidas em cada residência. O posto de saúde da comunidade, por sua vez, tem cadastradas 134 famílias, porque leva em consideração o fato de em uma mesma residência haver mais de uma família (onde acontece) para favorecê-las em algumas situações, a exemplo de poderem receber benefícios sociais como a bolsa família, a Declaração de Aptidão ao Pronaf - DAP, alguns créditos agrícolas, aposentadoria rural, etc.

Das 416 pessoas identificadas, sobressai o sexo feminino com 212; as pessoas do sexo masculino perfazem um total de 204. Do total dos moradores, $42,3 \%$ são crianças e adolescentes de 0 até 19 anos de idade, ou seja, 176 pessoas - sendo que $15,6 \%$ estão na faixa etária de 0 a 9 anos de idade (terceira maior faixa), e $26,7 \%$ estão na faixa etária de 10 a 19 anos de idade (primeira maior faixa). A segunda maior faixa de idade é a de 30 a 39 anos, que corresponde a população de adultos, perfazendo um total de 67 pessoas (16,1\% dos moradores). Portanto, a pirâmide etária da comunidade apresenta um maior alargamento na base (Figura 4). Esse fato aponta significativa expectativa de vida ao nascer, boa taxa de fecundidade, e a presença significativa de crianças e adolescentes entre a população do lugar, o que indica grande expectativa de futura renovação da população jovem e adulta da comunidade, e boa taxa atual de permanência no lugar por parte da camada jovem/adulta. Não podemos deixar de assinalar a grande diferença entre gêneros na faixa de 0 a 9 , os meninos são bem mais frequentes que as meninas sem que haja uma explicação evidente. Esta parece uma forma involuntária da comunidade em contribuir para a masculinização do campo. Já o envelhecimento da comunidade participante não pode ser observado como veremos a seguir.

Os dados em questão analisados contrapõem-se aos dados de algumas pesquisas de comunidades de assentamentos rurais na região, e até mesmo referente a outras regiões do país, onde é comum grande número de jovens migrarem do lugar para o espaço urbano, ou para outros estados, por falta de oportunidades. Tal realidade da CRFP pode ser entendida, dentre outros motivos, pelo sentimento de comunidade associado aos interesses pessoais e coletivos dos moradores, bem como o apego ao lugar ligado aos aspectos afetivos entre as pessoas e ao ambiente (Lima; Bomfim, 2009), e pela assistência dada pelo município, conforme poderá ser observado em outros dados analisados em seguida. 
Figura 4. Pirâmide etária da Comunidade Rural Fazenda do Povo de Ipiaú (Bahia), 2015

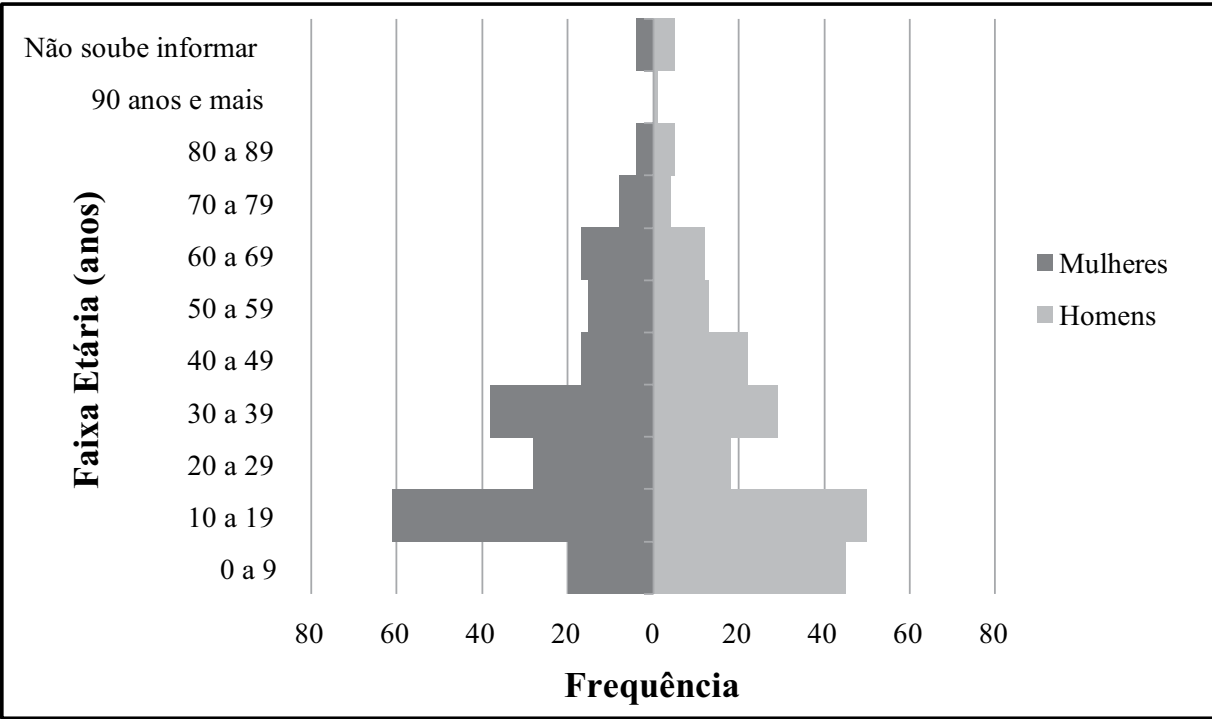

Fonte: Dados da pesquisa, 2015.

*O entrevistado apontou o sexo do familiar, mas não soube informar a idade deste.

No que consiste à questão escolaridade, para a última série concluída (independente de ainda estar estudando ou não), dos 416 moradores, 95 pessoas $(22,8 \%)$ estavam na faixa da $1^{\text {a }}$ a $4^{\text {a }}$ série incompleta; e 163 pessoas (39\%) encontravam-se entre as faixas de $5^{\mathrm{a}}$ a $8^{\mathrm{a}}$ série incompleta a ensino médio completo ou mais como última série concluída; e 55 pessoas $(13,2 \%)$ tinham o ensino médio ou mais como última série concluída; e números menores se encontravam em outras faixas.

Por se tratar de uma comunidade rural, esses números são significativos, pois normalmente se espera que a baixíssima escolaridade ou o analfabetismo sejam predominantes. Tais números podem ser explicados, dentre outros motivos, pelo fato de que, embora na comunidade tenha-se disponível apenas uma escola onde funciona da pré-escola ao ensino fundamental I (quarta série do quinto ano), o Poder Público Municipal disponibiliza transporte escolar (ônibus) nos três turnos (ida e volta) para os estudantes da comunidade se deslocar à sede municipal para estudar níveis mais elevados (escolas de ensino fundamental e médio; Educação 
Profissional Centro Territorial do Médio Rio das Contas - CETEP; e também para o Campus XXI da Universidade do Estado da Bahia - UNEB).

Segundo Cogo e Levien (2002), no Brasil a educação formal dos indivíduos do meio rural está lenta e progressivamente passando por um processo de aumento, embora esta ainda seja deficiente, pois não se alcançou a integralidade dos agricultores com formação primária completa $\left(1^{\mathrm{a}} \mathrm{a}\right.$ $8^{\mathrm{a}}$ séries), além de haver disparidades acentuadas entre as regiões do país, onde as Regiões Sul, Sudeste e Centro-Oeste praticamente conseguiram extinguir o analfabetismo, e as Regiões Norte e Nordeste evidenciam uma situação problemática.

Para a questão da saúde, a comunidade dispõe de um posto público mantido pelo Sistema Único de Saúde. Como essa unidade de saúde se constitui em um núcleo, então não apenas os moradores da comunidade são atendidos nele, mas também os moradores das localidades circunvizinhas. Em razão disso, neste estão cadastradas 470 famílias.

\section{Aspectos Econômicos}

Foi identificada uma renda total anual para a comunidade de R\$ 1.886.409,46, o que dá uma média anual de $\mathrm{R} \$ 16.994,68$ por família (111 famílias), e uma média anual de $\mathrm{R} \$ 4.534,64$ por pessoa da comunidade (416 pessoas). Já a média mensal de renda por pessoa da comunidade é de $\mathrm{R} \$ 377,88$. Ainda foi calculada a renda per capta mensal de cada família individualmente. $\mathrm{O}$ somatório da renda per capta mensal de cada família deu um valor total de $\mathrm{R} \$ 49.064,56$, o qual dividido pelas 111 famílias deu uma média de renda per capta de $\mathrm{R} \$ 442,02$ para cada família - inferior à renda per capita média de Ipiaú do ano de 2010 , que foi de $\mathrm{R} \$ 573,36$.

Conforme parâmetro de classificação de faixas de renda por classes sociais estabelecidos pela Secretaria de Assuntos Estratégicos - SAE da Presidência da República ${ }^{5}$ (2012), a maior frequência de famílias da comunidade $(44,14 \%)$ se encontram na faixa de média classe média, alta classe média e baixa classe alta, percebendo uma renda per capita mensal superior ou igual a $\mathrm{R} \$ 441,00$. A segunda maior frequência de famílias $(20,72 \%)$ se encontra na classe vulnerável, percebendo uma renda mensal

5 A classificação das faixas de renda por classes sociais da SAE (2012) são: $<$ R\$ 81,00 (extremamente pobre); < R\$ 162,00 (pobre, mas não extremamente pobre); < R \$ 291,00 (vulnerável); < R \$441,00 (baixa classe média); $>=\mathrm{R} \$ 441,00$ (média classe média, alta classe média e baixa classe alta).

Revista Geográfica de América Central No 57 ISSN 1011-484X, julio-diciembre 2016, pp. 289-331 
per capita inferior a $\mathrm{R} \$ 291,00$. Portanto, no que se refere à questão da renda familiar mensal per capta, dentro desse parâmetro estabelecido pela SAE, a comunidade se encontra em uma situação boa, pois $61,26 \%$ das famílias se encontram entre a baixa classe média $(<\mathrm{R} \$ 441,00)$ e a média classe média, alta classe média e baixa classe alta $(>=\mathrm{R} \$ 441,00)$. A Alta classe alta ficou de fora do perfil das famílias pesquisadas, tendo em vista que a maior renda mensal familiar per capita sinalizada foi de $<\mathrm{R} \$$ 2.480,00, ou seja, alcançando até a baixa classe alta.

Das 111 famílias, 47 tem em atividades agrícolas a maior significância na composição da renda (42,3\% das famílias); 18 famílias têm em atividades não agrícolas a maior significância na composição da renda (16,2\% das famílias); 44 famílias têm em benefícios sociais a base de composição da renda (39,6 das famílias); e duas famílias têm em atividades agrícolas e em atividades não agrícolas a mesma significância na composição da renda, ou seja, $1,8 \%$ das famílias. Esses dados deixam evidente que a maior parcela das famílias tem em atividades agrícolas a maior participação na composição da renda; e quase que o mesmo percentual de famílias tem em benefícios sociais a maior participação na composição da renda, evidenciando grande importância dos benefícios obtidos do Governo (aposentadoria, bolsa família, auxílio-doença e pensão) na manutenção de muitas famílias.

Dentre os 416 moradores, 29,1\% (121 pessoas) trabalham em atividades agrícolas dentro da própria comunidade, sendo 47 homens e 74 mulheres; 73 pessoas se enquadraram na categoria outras profissões não agrícolas realizadas dentro ou fora da comunidade; e 129 pessoas se enquadraram na categoria "não se aplica" que engloba idosos que não mais trabalham (aposentados) e crianças. Portanto, a maior parcela dos moradores que estão trabalhando tem como base de sustento o desenvolvimento de atividades agrícolas na comunidade. E 17,5\% das pessoas desenvolvem profissões não agrícolas na comunidade.

\section{Aspectos Produtivos}

A CRFP possui como seu suporte econômico a produção agrícola; seus moradores tem na utilização da terra a base para a reprodução da vida social e para a produção voltada à subsistência. Essa comunidade tem sua maior participação na economia municipal no setor primário, dentre os três setores de atividade, embora essa participação não seja expressiva por 
se tratar, em sua maioria, de produção familiar para subsistência (venda em feira-livre na cidade, em porta em porta na cidade, e, em casos isolados, em outras cidades, e também para o consumo familiar).

As principais atividades econômicas desenvolvidas na CRFP são a produção de hortaliças, frutíferas, cacau, mandioca, cana, bovino, aves, suínos e farinha; e de forma quase insignificante, a cachaça, o leite, ovos, peixe e ovelha. Embora a maior frequência de pessoas produza árvores frutíferas, no entanto, em sua maioria essa produção não é para a comercialização, e sim para o consumo da própria família.

A base de subsistência da maior parte das famílias é a produção de olericultura, com predomínio do cultivo de hortaliças (espécies folhosas), a qual é responsável de forma significativa pela geração de renda para as famílias que desenvolve esse tipo de produto em suas Unidades de Produção Familiar (UP) - identificou-se 77 Unidades Produtivas na CRFP. As maiores concentrações dessas unidades de produção se encontram em áreas de brejo, na agrovila. Para irrigar os cultivos as principais disponibilidades hídricas identificadas foram: rio, poço escavado, córrego, represa, nascente, riacho, água da chuva e poço artesiano.

No que consiste ao tamanho das Unidades de Produção Familiar na comunidade, o maior percentual desenvolve suas atividades agrícolas em apenas um ou menos de um hectare de terra. A explicação para esse fato está no transcurso da existência da comunidade, quando os primeiros residentes receberam maiores extensões de terras para produzir. Os derradeiros moradores receberam menores extensões de terras ou não tiveram acesso a estas para desenvolveram atividades agrícolas. Além disso, é comum ocorrer a comercialização não legalizada entre os próprios moradores ou com novos moradores.

O destino dado para a maior parcela do principal produto desenvolvido na comunidade (hortaliças) é a comercialização, sobretudo na feira livre da cidade de Ipiaú. Um número de 57 famílias, das que produzem hortaliças, sinalizaram desenvolver para a subsistência (que envolve ao mesmo tempo a comercialização e o autoconsumo); 54 famílias apontaram comercializar hortaliças na feira livre de Ipiaú (e dentre essas, algumas na de Itacaré e de Ibirataia), enquanto apenas três famílias sinalizaram vender a sua produção dentro da própria comunidade, e uma família não dispunha do produto no momento da pesquisa (Tabela 9). 
A principal forma de escoamento das hortaliças é por meio de transporte público (caminhão) gratuito fornecido pelo município aos sábados e aos domingos. Uma frequência de 47 famílias sinalizou se utilizar desse transporte para deslocar o produto da comunidade até a cidade para ser comercializado. Essa disponibilidade de transporte gratuito é importante para o produtor, pois contribui para a não redução do lucro final obtido com o produto.

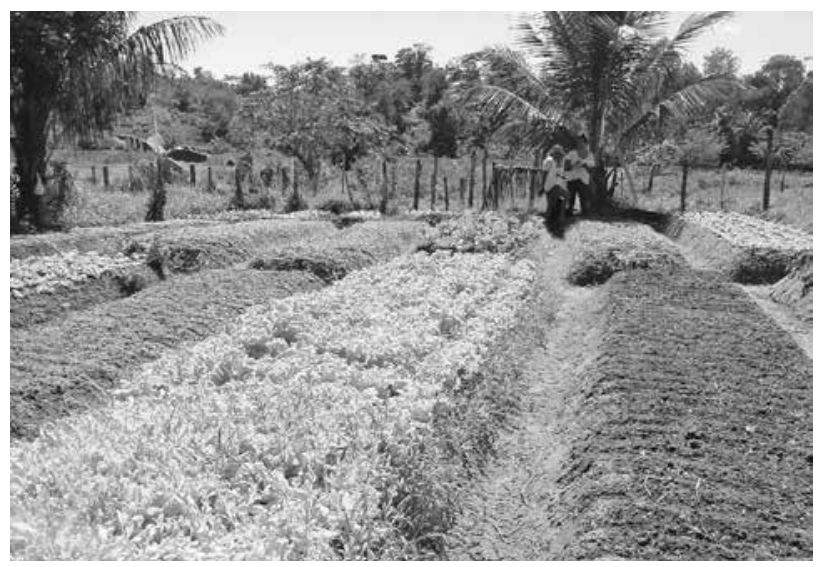

Figura 5. Produção de hortaliças na CRFP para comercialização na feira livre da cidade.

Foto: AGUIAR, P. C. B. de. (2015).

Figura 6. Agricultoras transportando hortaliças na CRFP, as quais posteriormente serão vendidas na cidade de Ipiaú

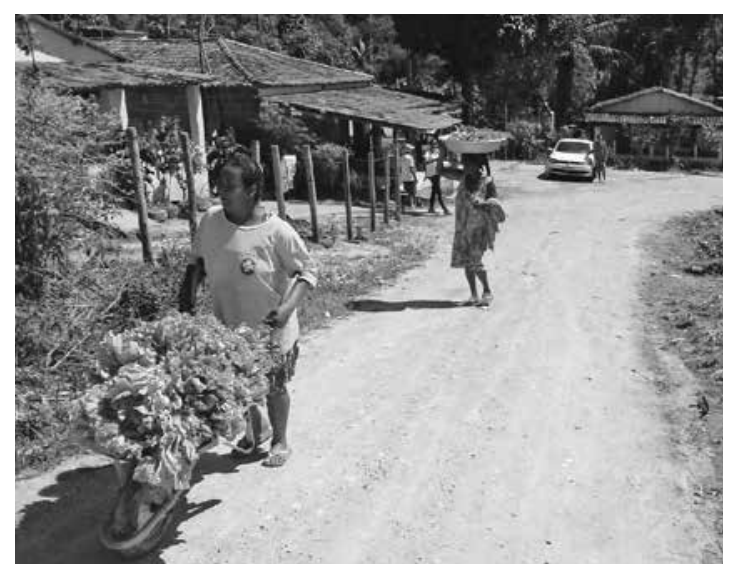

Foto: AGUIAR, P. C. B. de. (2015). 


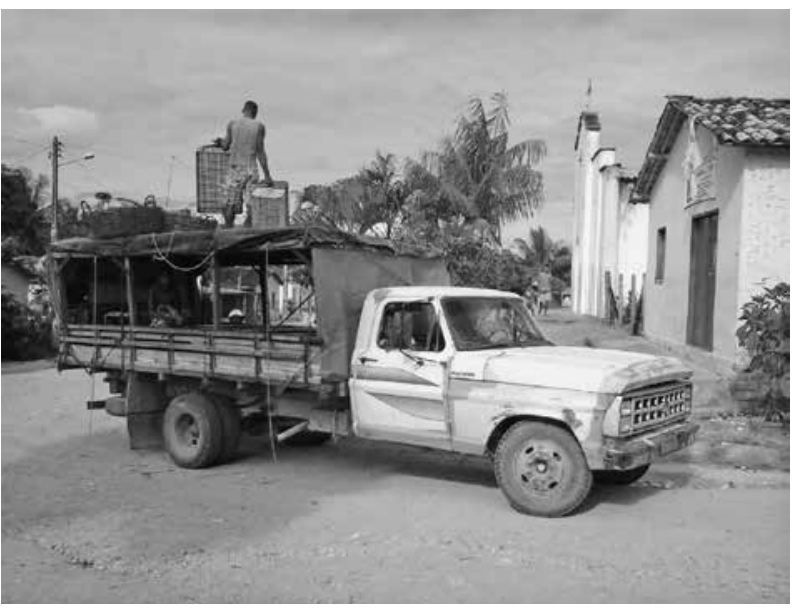

Figura 7. Transporte público do município para deslocamento dos produtos da CRFP para ser comercializados na cidade de Ipiaú

Foto: AGUIAR, P. C. B. de. (2015).

Figura 8. Cidade de Ipiaú

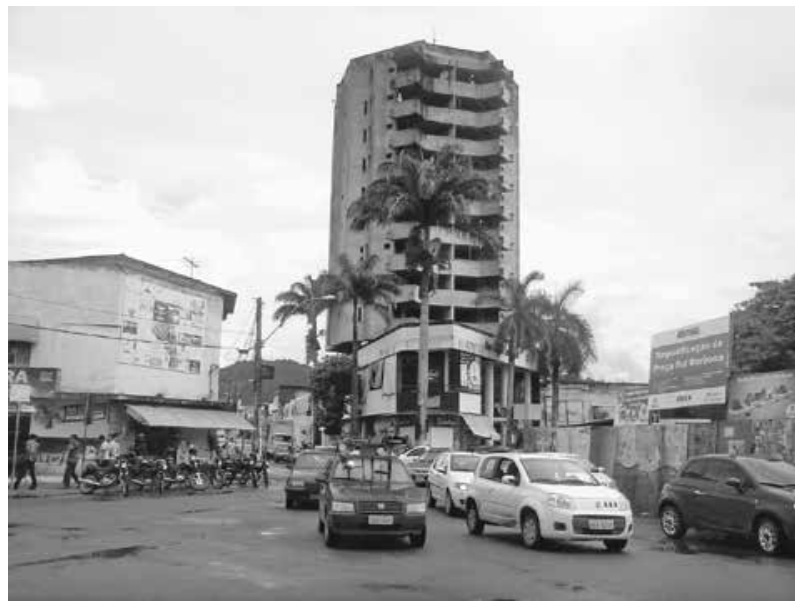

Foto: AGUIAR, P. C. B. de. (2015).

No entanto, no que consiste ao apoio técnico, as instituições ainda têm deixado muito a desejar, tanto para o processo de produção quanto o de agregação de valor e comercialização dos produtos. Na CRFP, há um alto nível de insatisfação em relação à assistência técnica recebida/ ou não recebida/ das principais instituições que atendem a comunidade. Mais de $56 \%$ dos representantes das famílias pesquisadas se mostraram insatisfeitos com as cinco instituições de assistência técnica apresentados: 
CEPLAC, EBDA, Secretaria de Agricultura Municipal, EMBRAPA e ADAB. A maior insatisfação foi em relação a EMBRAPA, com uma frequência de $66,7 \%$ dos entrevistados.

A negligência das instituições de assistência técnica, da liderança da comunidade, e o comodismo por parte dos moradores, tornam-se evidentes ao observar a frequência de entrevistados que sinalizaram terem recebido cursos de qualificação nos últimos anos: apenas seis pessoas $(5,4 \%)$, sendo que duas pessoas sinalizaram terem recebido cursos da ADAB; duas, do Poder Público Municipal; e duas, da CEPLAC. Enquanto 102 entrevistados $(92 \%)$ sinalizaram não terem recebido cursos nos últimos anos voltados para o trabalho agrícola.

Com relação às práticas adotadas para conservação do solo na Unidade Produtiva Familiar, as principais são: adubos orgânicos incluindo os fertilizantes químicos ou minerais (baixa solubilidade) - é o que se apresenta com maior frequência de utilização; adubos orgânicos e químicos ou minerais (níveis elevados de solubilidade) - se apresenta com a segunda maior frequência de utilização; fertilizantes químicos ou minerais; sistema de pousio natural ou nenhuma prática; e queimada.

O Controle de pragas, insetos, doenças e espécies de plantas invasoras nas Unidades de Produção Familiar são feitos, sobretudo, por: utilização de agrotóxicos (maior utilização); controle biológico (segunda maior frequência de utilização); nenhum método (terceira maior frequência); tratos e capturas manuais; e, controles biológicos e agrotóxicos, juntos.

Na comunidade, ainda é forte a utilização de agroquímicos para o manejo do solo, bem como para controlar as pragas, os insetos e as doenças nos cultivos, os quais têm prejudicado a fertilidade do solo, e consequentemente o desenvolvimento dos plantios, além de ter contribuído para o desequilíbrio biológico dos inimigos naturais de pragas agrícolas. Essas práticas são reflexos do padrão histórico insustentável de utilização da terra adotado no país, onde se privilegiou a produção em quantidade em detrimento da qualidade, e sem se preocupar com os impactos socioambientais gerados. 
Bruno, Nelma Lima; Aguiar, Paulo César Bahia de; Profice, Christiana Cabicieril; Ferraz, Marcelo Inácio Ferreira. Socioeconomic analysis of rural community fazenda do Povo, Ipiaú Municipality, Bahia, Brazil

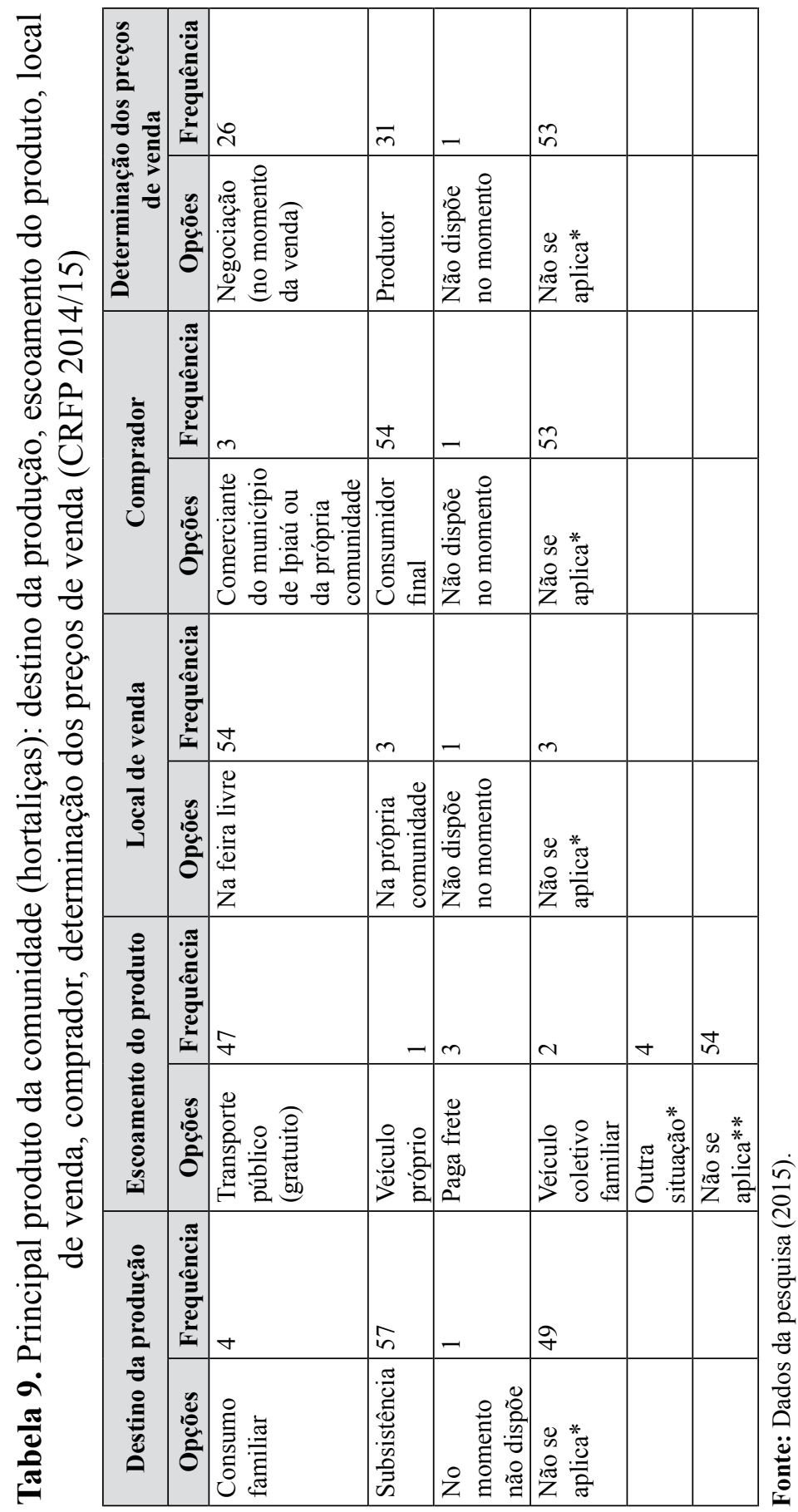




\section{Desafios ao Desenvolvimento Socioeconômico da CRFP}

A ideia de desenvolvimento é algo amplo e complexo, pois diferentes nuanças devem ser levadas em consideração no seu entendimento. Para Furtado (1984), o desenvolvimento está associado diretamente à realização das potencialidades do homem ao considerar que as sociedades são vistas como sendo desenvolvidas na medida em que nelas o homem mais cabalmente logra satisfazer suas necessidades, manifestar suas aspirações e exercer seu gênio criador. Caporal e Costabeber (2000) entendem que o desenvolvimento, em sua formulação mais ampla, significa a realização de potencialidades socioculturais e econômicas de uma sociedade em perfeita sintonia com seu entorno ambiental. A sustentabilidade passa então a ser o farol que guiará pesquisas e políticas públicas, mesmo o público em geral adota sua essência como parte do politicamente correto e socialmente justo. Há um consenso de que os ambientes e recursos naturais devem ser protegidos e de que a produção e o consumo devem ser continuamente repensados de modo a gerar o mínimo de impacto possível sobre a natureza que, por sua vez deve recuperar grandes áreas atualmente degradadas, nos distintos biomas de nosso planeta. A expansão das liberdades de Amartya Sen (2010) aponta para o desenvolvimento como a realização do bem estar de todos, conforme suas próprias referências culturais, de forma transparente e equitativa na oferta de oportunidades às pessoas. Segundo González (1999), o desenvolvimento social das comunidades rurais ocorre não somente a partir das atividades econômicas ou mediante o fortalecimento de pequenos, médios e grandes negócios, mas sim, na perspectiva de que estes criem circuitos de trabalhos necessários para aumentar renda e bem-estar. Em tal perspectiva, é necessária a criação de condições para o acesso por parte dos residentes aos meios de produção, bem como o apoio para que as famílias se insiram favoravelmente a partir de sua própria comunidade, enraizados no seu próprio ambiente como sujeitos e não como objetos do desenvolvimento.

Comumente confunde-se desenvolvimento socioeconômico com crescimento econômico. Embora muitos estudiosos entendam que para ocorrer o desenvolvimento socioeconômico é necessário haver o crescimento econômico, no entanto, apenas o crescimento econômico não é suficiente para caracterizar o desenvolvimento da economia e da sociedade, pois o que dizer quando esse crescimento se dá apenas no sentido 
de beneficiar camadas da sociedade em detrimento da maioria (os menos favorecidos)? Tal fato acaba por ser elemento propiciador da geração ou agravamento de sérios problemas sociais. Historicamente, o crescimento econômico tem sido praticado na sociedade capitalista no sentido da acumulação de riquezas por parte de um conjunto restrito de países, e por algumas camadas da sociedade. Nesta direção, a sustentabilidade tridimensional de Mauerhofer (2008) se revela uma referência holística, mas ao mesmo tempo realista diante da finitude do capital natural, que em última instância é quem dá suporte ao capital social que por sua vez é a base sobre a qual o capital econômico se desenvolve.

Para efetivamente ocorrer um desenvolvimento socioeconômico, quer seja em uma sociedade em nível nacional, ou mesmo em uma pequena comunidade, é necessário haver socialização dos benefícios obtidos com o crescimento econômico, de forma a se alcançar melhoria na qualidade de vida da população como um todo, ou seja, melhora dos indicadores econômicos, sociais, infraestruturais, de trabalho e ambientais.

$\mathrm{O}$ atual modelo de desenvolvimento adotado pela sociedade industrial capitalista com seu estilo de vida consumista, ou mesmo o tão propagado desenvolvimento sustentável com a formulação do seu conceito pelas elites em esfera governamental, não tem sido capaz de responder as inquietações e contradições advindas da relação sociedade-natureza, no sentido de garantir o desenvolvimento da sociedade humana e suas instituições, em diferentes regiões e em suas peculiaridades culturais e institucionais, possibilitando ao mesmo tempo a conservação da natureza com qualidade, tanto para o presente, quanto para o futuro.

Diversas pesquisas, em diferentes contextos, têm revelado significativos avanços no processo de implantação de assentamentos de reforma agrária do ponto de vista quantitativo. No entanto, esses estudos têm sinalizado alguns aspectos negativos que em sua a maioria tem sido muito comum aos casos dos assentamentos analisados, a exemplo da necessidade emergencial da adoção de políticas públicas mais eficientes no sentido de contribuir para o fortalecimento de indicadores primordiais para a manutenção desses ambientes.

A Comunidade Rural Fazenda do Povo necessita melhorar a qualidade de alguns indicadores, sobretudo no que se refere aos aspectos da produção, melhoria na gestão de resíduos, e no que se refere à baixa 
frequência de relações sociais participativas. Os aspectos mais negativos identificados que requerem ser corrigidos estão ligados aos aspectos produtivos, como o não recebimento de assistência técnica nos últimos anos da parte das instituições competentes; a alta incidência de utilização de agroquímicos no manejo do solo e para o controle de insetos-pragas e doenças; e a pequena extensão de terra para cada família produzir - e a ausência desta para algumas famílias.

Como a presença de crianças e jovens na composição da população da CRFP é significativa (e significativa é a taxa de permanência no lugar), é preciso planejamento de longo prazo voltado para essas camadas da população, para que possam ser absorvidas futuramente em atividades na própria comunidade. Portanto, há a necessidade da criação de oportunidades no lugar para esses jovens atuais, e para os futuros jovens, para que não migrem para outros lugares ou fiquem susceptíveis a se envolverem em vícios sociais (drogas, prostituição, roubos, etc.) por falta de opção de ocupação. Sugere-se, aqui, o desenvolvimento de um plano de desenvolvimento para a CRFP de longo prazo, o qual priorize os aspectos mais frágeis da comunidade no sentido de buscar soluções ou alternativas para eles, e ao mesmo tempo reforce os aspectos positivos identificados e as suas potencialidades. É primordial a comunidade buscar a sua autonomia no que se refere à tomada de decisão e para alcançar a autogestão - embora não ignorando a esfera governamental que a mantém (o Poder Público Municipal de Ipiaú).

\section{Considerações Finais}

Por meio de uma visão holística sobre a socioeconomia da CRFP no contexto municipal e regional, tendo por base de análise os resultados obtidos com a pesquisa, identificou-se que a referida comunidade se encontra em situação favorável em muitos aspectos; algo evidenciado por alguns indicadores. A constituição atual da comunidade é predominantemente de adolescentes (de 10 a 19 anos de idade), jovens/adultos (de 30 a 39 anos de idade) e crianças (de 0 a 9 anos de idade) - nessa ordem. O nível de instrução, se considerar a realidade de outros espaços rurais da região e do país, também apresenta aspectos positivos, com a presença de significativo número de adolescentes e jovens com ensino fundamental completo ou cursando o ensino médio (favorecido pela assistência do Poder Público por meio de transporte escolar nos três turnos). 
Bruno, Nelma Lima; Aguiar, Paulo César Bahia de; Profice, Christiana Cabicieril; Ferraz, Marcelo Inácio Ferreira. Socioeconomic analysis of rural community fazenda do Povo, Ipiaú Municipality, Bahia, Brazil

Outro aspecto de grande importância a ser destacado na comunidade, de forma positiva, é o grande número de pessoas ocupadas em algum tipo de atividade, quer seja dentro da comunidade (a maior parcela) ou mesmo fora dela, cuja renda obtida é a base de sustento da família. A renda obtida pelas famílias além ser satisfatória para atender as necessidades básicas, no que se refere à questão da renda familiar mensal per capta, dentro dos parâmetros estabelecidos pela Secretaria de Assuntos Estratégicos da Presidência da República, coloca a comunidade em uma situação boa, pois $61,26 \%$ das famílias se encontram entre a baixa classe média $(<\mathrm{R} \$$ $441,00)$ e a média classe média, alta classe média e baixa classe alta $(>=$ $\mathrm{R} \$ 441,00)$. A CRFP apresenta fraca dependência de benefícios sociais do Governo para complementar a renda familiar, ou tendo-o como a base da renda da família.

Como aspectos mais negativos identificados estão a alta incidência de utilização de agroquímicos no manejo do solo e para o controle de insetos-pragas e doenças; e também a pequena extensão de terras para cada família produzir. A despeito dos problemas e algumas situações não satisfatórias existentes na CRFP, a incidência do sentimento de apego ao lugar, marcado pelo afeto e emoções por parte dos moradores, contribui para explicar a significativa ocorrência de permanência no lugar e a existência da comunidade no tempo. Seu caráter singular no plano nacional dos assentamentos rurais nos indicam alguns aspectos que podem ser posteriormente abordados. No mesmo momento em que o movimento das ligas camponesas era perseguido e desmantelado pelas forças da ordem militar que apoiavam os grandes proprietários a CRFP nascia como uma comunidade relativamente autônoma, visto que nela a posse da terra não foi resultante de disputa contra os proprietários, mas resultado de doação da parte de um prefeito, Euclides Neto, que viabilizou o assentamento das famílias iniciais. Fundou-se uma comunidade rural a partir da necessidade de trabalhadores rurais sem trabalho e sem terra. Alheia aos princípios da sustentabilidade a comunidade se desenvolveu atendendo em medida a alguns de seus critérios. Na CRFP não há nem pobres nem ricos, a equidade entre seus membros é talvez a mais valiosa conquista na direção da sustentabilidade. A produção de diferentes culturas agrícolas também garante uma alimentação diversificada para os moradores da comunidade. Contudo, a baixa participação política pode por em risco essa vantagem, prejudicando 
a mobilização comunitária pela melhoria do acesso e qualidade de serviços como educação, saúde e transporte. Os aspectos referentes às práticas produtivas e utilização dos recursos naturais também constituem atual vulnerabilidade na sustentabilidade ambiental da comunidade. Nesta direção é evidente a adequação de capacitação dos trabalhadores rurais no que se refere à saúde e a utilização de fertilizantes e defensivos químicos. A CRFP nos indica que investir na agricultura familiar e na promoção do bem estar e qualidade de vida das comunidades rurais é de fato um forte vetor de desenvolvimento socioeconômico em nosso país orientado para a sustentabilidade ambiental.

\section{Referências}

Andrade, M. C. (1994). O Desafio Ecológico: Utopia e Realidade. São Paulo: HUCITEC.

Bergamasco, S. M. P. P. (1997). “A realidade dos assentamentos rurais por detrás dos números”. Estudos Avançados, 11 (31), 37-49.

Brandemburg, A. (2010). "Do rural tradicional ao rural socioambiental". Ambiente \& Sociedade, XIII (2), Campinas, p.p. 417-428.

Camarano, A. A. y Abramovay, R. (1998). Exxodo rural, envelhecimento e masculinização no Brasil: panorama dos últimos cinquenta anos. Revista Brasileira de Estudos de População, 15(2), 45-65.

Caporal, F. R. y Costabeber, J. A. (2000). "Agroecologia e Desenvolvimento Rural Sustentável: perspectivas para uma nova extensão rural". Agroecologia e Desenvolvimento Rural, 1(1).

Caporal, F. R. y Costabeber, J. A. (2002). “Análise Multidimensional da Sustentabilidade : Uma proposta Metodológica a partir da Agroecologia". Agroecologia e Desenvolvimeno Rural Sustentável, 3 (3).

Carneiro, M. J. (2013). "Ruralidade: novas identidades em construção". Estudos Sociedade e Agricultura, pp. 53-75.

Cogo, N. P. y Levien, R. (2002). "Perspectivas do manejo e da conservação do solo e da água no Brasil”. In: Araújo, Quintino Reis de. (coord.). 500 Anos de uso do solo no Brasil, Ilhéus: Editus, pp. 51-164.

Fernandes, B. M. (2008). "27 anos do MST em luta pela terra". In: Reforma Agrária e Desenvolvimento: Desafios e rumos da política de assentamentos rurais. Brasília, pp.27-52. 
Freitas, H. I. y Germani, E G. I. (2010). “A questão da (reforma) agrária e a política de desenvolvimento territorial rural no litoral sul da Bahia". Porto Alegre, UFRGS: Anais do XVI Encontro Nacional de Geógrafos (ENG 2010).

Furtado, C. (1984). Cultura e desenvolvimento em época de crise. Rio de Janeiro: Paz e Terra.

Góis, C. W. L. (2005). Atividade e consciência. Brasil: Instituto Paulo Freire, Fortaleza.

González, H. (1999). "Situación actual, tendencias y retos del desarrollo rural en Costa Rica". XI Congreso Nacional Agronômico / I Congreso Nacional de Extensión.

Instituto Nacional de Colonização e Reforma Agrária, INCRA. (2011). Relação dos Projetos de Reforma Agrária do Brasil. Diretoria de Obtenção de Terras e Implantação de Projetos de Assentamento (DT), Brasília, DF.

Instituto Nacional de Colonização e Reforma Agrária, INCRA. (2015). Relação dos Projetos de Reforma Agrária do Brasil. Diretoria de Obtenção de Terras e Implantação de Projetos de Assentamento (DT), Brasília, DF.

Kageyama, A. (2004). Desenvolvimento Rural: Conceito e Medida. Cadernos de Ciência \& Tecnologia, 21(3), 379-408.

Lima, D. M. A. y Bomfim, Z. A. C. (2009). "Vinculação afetiva pessoaambiente: diálogos na psicologia comunitária e psicologia ambiental". Psico, 40(4), 491-497.

Mauerhofer, V. (2008).3-D Sustainability: an approach for priority setting in situation of conflicting interests towards a Sustainable Development. Ecological Economics, 64(3), 496-506.

Meliani, P. F. (2014). Políticas Públicas e Produção do Espaço no Sul da Bahia: Análise da Situação por Município dos Projetos de Reforma Agrária na Microrregião Ilhéus-Itabuna. Revista Movimentos Sociais e Dinâmicas Espaciais, 3(1), 231-255.

Programa das Nações Unidas para o Desenvolvimento, PNUD/ Instituto de Pesquisas Econômicas Aplicadas, IPEA/ Fundação João Pinheiro. (2000). Novo Atlas do Desenvolvimento Humano no Brasil. Brasil: PNUD. 
Rocha, L. B. (2008). A região cacaueira da Bahia - dos coronéis do cacau à vassoura-de-bruxa: saga, percepção, representação. Ilhéus: Editus.

Secretaria de Assuntos Estratégicos, SAE. <http://www.sae.gov.br/imprensa/sae-na-midia/governo-define-que-a-classe-media-tem-renda-entre-r-291-e-r-1-019-cidade-verde-em-24-07-2013/>

Sen, A. (2010). Desenvolvimento como liberdade. São Paulo: Companhia das Letras.

Toledo, V. M. (1996). "Principios etnoecologicos para el desarrolo sustentable de comunidades campesinas e indígenas". Temas Clave, CLAES, (4), Centro de Ecología de la UNAM, México <http://infocuib.laborales.unam.mx/ ec08s02c/archivos/data/1/12.pdf>

Youmans, R. C. (1982). Factors That Influence Rural Development: The State of the Art, Western Rural Development Center. Portland, Oregon.

Zugaib, A. C. C., y Andrade, F. C. (2015). "Uma Análise dos Mercados Nacional e Internacional de Cacau e Chocolate". In: Gomes, Andréa da Silva; Pires, Mônica de Moura (Org.). CACAUICULTURA: estrutura produtiva, mercados e perspectivas. Ilhéus, BA: Editus, pp. 207-227. 